\title{
35. GEOTECHNICAL PROPERTIES AND CONSOLIDATION CHARACTERISTICS OF NORTH PACIFIC SEDIMENTS, SITES 881, 883, AND 885/886 ${ }^{1}$
}

\author{
Anne K. Rutledge, ${ }^{2}$ John A. Roberts, ${ }^{3}$ Thomas H. Orsi, ${ }^{2}$ William R. Bryant, ${ }^{2}$ and Aarno T. Kotilainen ${ }^{4}$
}

\begin{abstract}
Consolidation tests performed on samples representative of the major sediment types recovered during Ocean Drilling Program Leg 145 indicate that the diatom oozes and clays of Sites 881,883 , and $885 / 886$ may be characterized as normally consolidated, moderately to highly compressible, and slightly permeable to impermeable. Comparison of field and laboratory consolidation curves reveals a disparity between porosity variations caused by loading (i.e., burial) observed in situ and under laboratory conditions. The field consolidation curves indicate that the high porosities characteristic of diatomaceous oozes are preserved in spite of the increasing sediment load, most likely the result of a resistance to consolidation due to the structural strength of the diatom frustules, whereas the laboratory consolidation curves $\left(e-\log P^{\prime}\right)$ reveal a reduction of porosity with increasing load as expected. Use of the empirical relationship between the ratio of undrained shear strength to effective overburden stress and the state-of-consolidation for a sediment supports biostratigraphic and gamma-ray attenuation porosity evaluator (GRAPE) correlation data, suggesting an erosional unconformity in the upper $20 \mathrm{mbsf}$ of Hole 885A. A medical CT (or CAT) scanner was found to be useful in evaluating the suitability of samples selected for consolidation testing. With increased availability, this device could conceivably replace, or at least provide a valuable supplement to, X-radiography for the nondestructive three-dimensional examination of whole core samples.
\end{abstract}

\section{INTRODUCTION}

The application of geotechnical testing methods to marine sediments by geoscientists has become a widely accepted practice over the past 20 years. These techniques supplement the more common sedimentological analyses (e.g., textural and mineralogical analyses, particle identification, and sedimentary structure analyses) used to enhance our understanding of the dominant geologic processes (Bryant et al., 1974, 1981; Keller, 1974; Bennett and Nelson, 1983; Pittenger et al., 1989; Bryant and Rack, 1990). Standard Ocean Drilling Program (ODP) shipboard physical property measurements include the index properties (water content, wet and dry bulk density, GRAPE bulk density, grain density, void ratio, and porosity), sediment shear strength, and compressional-wave velocity. These data are essential as input for acoustic models of the seafloor and sediment mass-accumulation calculations. Sediment index properties are closely linked to the sedimentological processes that have acted upon the sediment. Realization that downhole variations in physical properties often reflect even minor lithologic changes, in addition to the physical state of the sediment, has led to use of these data as a stratigraphic tool (Taylor, 1984; Pittenger, 1992). Shear strength, for example, is a function of mineralogy, grain size, particle type, water content, diagenesis, depth of burial, and stress history. Consequently, information regarding shear strength variation with increasing depth below the seafloor can contribute to our understanding of the postdepositional processes affecting marine sediments. In addition to the shipboard physical property analyses, consolidation testing is used by marine geologists to gain insight into a sediment's

' Rea, D.K., Basov, I.A., Scholl, D.W., and Allan, J.F. (Eds.), 1995. Proc. ODP, Sci. Results, 145: College Station, TX (Ocean Drilling Program).

${ }^{2}$ Department of Oceanography. Texas A\&M University, College Station, TX 77843, U.S.A.

${ }^{3}$ Marine Geoscience Research Group, Department of Earth Sciences, University of Wales College of Cardiff, P.O. Box 914, Cardiff CF1 3YE, United Kingdom.

${ }^{4}$ Department of Earth Sciences, University of Cambridge, Downing Street, Cambridge CB2 3EQ, United Kingdom. stress history and to determine the magnitude and timing of the porosity and permeability changes induced by the addition or removal of overburden by sedimentary processes.

The primary objective of Leg 145 was to improve our knowledge of the paleoceanography and paleoclimatology of the North Pacific Ocean. The sites selected to meet this objective also presented us an opportunity to expand upon the study of the geotechnical properties and consolidation characteristics of the North Pacific sediments begun on Deep Sea Drilling Project (DSDP) Leg 86. The purpose of this study is to examine the extensive set of physical property data from Sites 881,883 , and $885 / 886$ and to augment these data with consolidation and permeability test results.

\section{METHODS}

\section{Shipboard Physical Properties}

The shipboard physical properties measurements made during Leg 145 were performed using standard ODP methods as detailed in Boyce (1976) and the "Explanatory Notes" chapter in the Leg 145 Initial Reports volume (Rea, Basov, Janecek, Palmer-Julson, et al., 1993). Summaries of the shipboard physical properties results for Sites 881,883 , and $885 / 886$ may be found in their respective chapters in Rea, Basov, Janecek, Palmer-Julson, et al. (1993). The sampling strategy used for these sites was designed to maximize the physical property sampling resolution within the time constraints imposed by shipboard operations. Index property, compressional-wave velocity, and shear strength measurements were made two per section in cores from Holes $881 \mathrm{~B}$ and $883 \mathrm{~A}$, one per section in cores from Holes $881 \mathrm{C}, 883 \mathrm{C}, 885 \mathrm{~A}, 886 \mathrm{~A}, 886 \mathrm{~B}$, and $886 \mathrm{C}$ and Cores $145-883 \mathrm{~B}-1 \mathrm{H}$ and $-30 \mathrm{H}$ through $-86 \mathrm{X}$, and one per every two sections in cores from Hole 881D.

A continuous record of wet bulk density was generated for all of the cores from Sites 881,883 , and $885 / 886$ using the gamma-ray attenuation porosity evaluator (GRAPE) on the multisensor track (MST). Bulk density is calculated from gamma-ray attenuation using the relationship (Evans, 1965): 
Table 1. Grain-size results for consolidation samples from Sites 881, 883, and 885/886.

\begin{tabular}{|c|c|c|c|c|}
\hline \multirow[b]{2}{*}{$\begin{array}{l}\text { Core, section. } \\
\text { interval }(\mathrm{cm})\end{array}$} & \multirow[b]{2}{*}{ Sediment type } & \multicolumn{3}{|c|}{ Grain size } \\
\hline & & $\begin{array}{l}\text { Sand } \\
(\%)\end{array}$ & $\begin{array}{l}\text { Silt } \\
(\%)\end{array}$ & $\begin{array}{l}\text { Clay } \\
\text { (\%) }\end{array}$ \\
\hline \multicolumn{5}{|l|}{$145-886 C-$} \\
\hline $2 \mathrm{H}-4,140-150$ & Spicule clay & 7.83 & 24.96 & 67.21 \\
\hline $3 \mathrm{H}-5,140-150$ & Diatom ooze with clay & 33.01 & 22.66 & 44.32 \\
\hline $4 \mathrm{H}-4,138-150$ & Diatom ooze & 58.54 & 8.98 & 32.48 \\
\hline $6 \mathrm{H}-1,140-150$ & Diatom ooze with clay & 49.66 & 4.57 & 45.77 \\
\hline $7 \mathrm{H}-5,138-150$ & Clay & 0.36 & 7.16 & 92.47 \\
\hline $8 \mathrm{H}-5,138-150$ & Red clay & 0.59 & 11.69 & 87.73 \\
\hline \multicolumn{5}{|l|}{$145-881 \mathrm{C}-$} \\
\hline $3 \mathrm{H}-4,138-150$ & Clayey diatom ooze & 10.11 & 73.60 & 16.28 \\
\hline $12 \mathrm{H}-3,138-150$ & Clayey diatom ooze & 11.83 & 45.25 & 42.93 \\
\hline $21 \mathrm{H}-5,138-150$ & Diatom ooze & 37.92 & 26.16 & 35.93 \\
\hline \multicolumn{5}{|l|}{$145-883 \mathrm{~B}-$} \\
\hline $6 \mathrm{H}-5,138-150$ & Clay with diatoms & 15.25 & 31.95 & 52.79 \\
\hline $10 \mathrm{H}-2,138-150$ & Clayey diatom ooze & 23.03 & 27.53 & 49.44 \\
\hline $48 X-5,138-150$ & Diatom ooze with clay and calcite & 27.76 & 39.73 & 32.51 \\
\hline
\end{tabular}

$$
\rho_{b}=\left(\frac{1}{\mu d}\right) \ln \left(\frac{I_{0}}{I}\right),
$$

where:

$$
\begin{aligned}
& \rho_{b}=\text { bulk density }\left(\mathrm{Mg} / \mathrm{m}^{3}\right), \\
& \mu=\text { Compton mass attenuation }\left(\mathrm{cm}^{2} / \mathrm{g}\right), \\
& d=\text { core diameter }(\mathrm{cm}), \\
& I_{0}=\text { source intensity }(\text { counts } / \mathrm{s}), \text { and } \\
& I=\text { intensity through sediment (counts/s). }
\end{aligned}
$$

Using this relationship to calculate sediment density assumes that the mass attenuation coefficient of quartz is an acceptable estimation for the actual mass attenuation coefficient of the sediment. Bulk density values obtained in this manner are approximately $10 \%$ higher than those obtained using volumetric techniques. Boyce (1976) attributed this discrepancy to the $\sim 10 \%$ difference in the Compton mass attenuation coefficients of water and quartz. High-porosity sediments, such as the diatom oozes characteristic of the North Pacific, are particularly subject to this type of error. The $0.1 \mathrm{~g} / \mathrm{cm}^{3}$ offset between the GRAPE data and the discrete measurements reported in the Initial Reports volume (Rea, Basov, Janecek, Palmer-Julson, et al., 1993) results largely from the inadvertent omission of this correction from the algorithm used to calculate bulk density from gamma-ray attenuation (Moran, 1993). The GRAPE data presented here have been corrected for this offset using the Boyce equation (Boyce, 1976):

$$
\rho=\frac{\left(\rho_{b c}-\rho_{f c}\right)\left(\rho_{g}-\rho_{f}\right)}{\left(\rho_{g c}-\rho_{f c}\right)}+\rho_{f},
$$

where:

$$
\begin{aligned}
& \rho=\text { true bulk density, } \\
& \rho_{b c}=\text { calculated bulk density (using mquartz), } \\
& \rho_{f}=\text { true fluid density }=1.024 \mathrm{Mg} / \mathrm{m}^{3}, \\
& \rho_{f c}=\text { calculated fluid density (using mquartz) }=1.128 \mathrm{Mg} / \mathrm{m}^{3} \text {, } \\
& \rho_{g}=\text { true grain density, and } \\
& \rho_{g c}=\text { calculated grain density (using mquartz) }=2.65 \mathrm{Mg} / \mathrm{m}^{3} \text {. }
\end{aligned}
$$

Before plotting, the GRAPE data were smoothed using a 29-point running average to improve the legibility of the plots while reducing the resolution as little as possible.

\section{Consolidation Testing}

All consolidation test samples were subsampled for percent sandsilt-clay analyses. The grain-size analyses followed standard sieve and pipette analysis techniques as set forth in Folk (1974). The results of these analyses are presented in Table 1. Uniaxial consolidation tests and falling-head permeability measurements were performed at the
Texas A\&M University (TAMU) Department of Civil Engineering Soil Mechanics Laboratory using standard Soiltest load frames and fixed-ring oedometers. Twelve samples $(6.38 \mathrm{~cm}$ diameter $\times 2.54 \mathrm{~cm}$ height) were loaded incrementally to $800 \mathrm{kPa}$, unloaded to $50 \mathrm{kPa}$, then reloaded to a maximum of $3200 \mathrm{kPa}$ on a $24-\mathrm{hr}$ loading schedule. Time-compression curves were produced for each load using the techniques discussed in Head (1988). The void ratio at 24-hr (e24), coefficient of consolidation $\left(c_{v}\right)$, coefficient of volume compressibility $\left(m_{v}\right)$, and the permeability $(k)$ were calculated based on the data contained in the time-compression curves. At the end of each test, plots of void ratio vs. the logarithm of the effective stress $\left(e-\log P^{\prime}\right)$ were generated. The preconsolidation $\left(P_{\mathrm{c}}{ }^{\prime}\right)$ stress of each consolidation sample was determined from the $e$-Log $P^{\prime}$ plot using the Casagrande technique (Casagrande, 1936). The overconsolidation ratio (OCR), defined as the ratio of the preconsolidation stress to the existing effective overburden $\left(P_{o}{ }^{\prime}\right)$, provides insight into the stress history of the area and can reveal the presence of erosional or nondepositional hiatuses that are otherwise undetectable. By determining the degree of consolidation, we can estimate the amount of overburden removed in the case of overconsolidated sediments, and detect areas subject to rapid sedimentation or excess pore pressures in the case of underconsolidated sediments. A thorough discussion of the limitations of the Casagrande technique as applied to marine sediments may be found in Bryant and Rack (1990). Plots of the ratio of undrained shear strength to effective overburden stress $\left(S_{u} / P_{o}^{\prime}\right)$ vs. depth have been generated to supplement the state-of-consolidation data obtained from the uniaxial consolidation tests (Skempton, 1970). In general, the permeability values calculated from the $c_{v}$ for each load applied during the test are indicative of the magnitude of change in permeability that occurred as a result of burial.

\section{CT Scan Examination}

Terzaghi's (1943) theory of consolidation is based on a number of assumptions, one of which is sample homogeneity. The possible effects of inhomogeneities on test results are many. Gravel or shells, for instance, can produce anomalously low compressibility, whereas unusually high compressibility and permeability could result from open burrows or cracks. Furthermore, the quality of consolidation test results are strongly influenced by sample quality. As a result, the ability to assess the degree of sample disturbance prior to testing is highly desirable. Worst case in these scenarios is an invalidation of test results.

Verifying the homogeneity of a consolidation sample is difficult and accomplished mainly through visual inspection. Unfortunately, structures may be internal or so subtle they remain invisible to the unaided eye. X-radiography has long been used to examine whole round samples, but superimposing three-dimensional structures onto two-dimensional photographic film complicates interpretation. In a 
different approach, we used X-ray computed tomography (CT or CAT scanning) to evaluate the internal structure of consolidation samples from Hole $886 \mathrm{C}$. The technique is fast, quantitative, and extremely sensitive to subtle density contrasts. Moreover, visualizing internal structures (if present) may help evaluate the consolidation test results.

The Technicare $\Delta-100 \mathrm{CT}$ scanner used for this study (Pl. 1) is a second-generation translate-rotate brain scanner (Vinegar and Wellington, 1987). The sample is centered within a circular gantry supporting the X-ray source and detectors. Rotating about the test sample, each source-receiver location provides a line integral measurement of X-ray attenuation called a ray sum. After measuring and combining over a span of locations greater than $180^{\circ}$, transformation of the ray sums by a filtered back-projection reconstruction algorithm results in a two-dimensional grid of X-ray attenuation values (Brooks and Di Chiro, 1975). The density of the material is the predominant factor determining X-ray attenuation at the energies of $120 \mathrm{kV}$ used for most medical scanners (McCullough, 1975). CT scanners convert $\mathrm{X}$-ray attenuation to a parameter called the Hounsfield unit $(H U)$ by normalizing it to the attenuation coefficient of water, and linearize the scale by arbitrarily assigning $H U_{\text {water }}$ to a value of zero and $H U_{\text {air }}$ to $-1000 \mathrm{HU}$. (The Hounsfield unit is named after G.N. Hounsfield, the Nobel prize-winning inventor of the CT scanner; Hounsfield, 1973). CT studies of unconsolidated sediments have all verified the strong linear correlation between sediment bulk density and X-ray attenuation, usually reporting correlation coefficients greater than 0.9 (e.g., Petrovic et al., 1982; Anderson et al., 1988; Warner et al., 1989; Orsi et al., 1992; Orsi, 1994).

The scanner has an automatic micropositioning table to move the sample in and out of the image plane with a precision of about $60 \mu \mathrm{m}$. The sediment core was positioned horizontally and fixed to the CT scanner positioning table in the center of the imaging plane. A slice thickness of $7 \mathrm{~mm}$ full width, half maximum (FWHM) and an inplane resolution of $0.4 \mathrm{~mm}$ were used for the samples in this study. All images were acquired at $120 \mathrm{kV} / 25 \mathrm{~mA}$ as the sample position was moved incrementally through the image plane at $7-\mathrm{mm}$ steps. The resulting nonoverlapping images are aligned perpendicular to the cylindrical axis of each core. Each reconstructed CT data file is a 256 $\times 256$ numerical array that was downloaded from magnetic tape for analysis on a Macintosh II computer using Spyglass Transform visualization software.

\section{RESULTS}

\section{Shipboard Physical Properties}

A complete set of the shipboard physical property results may be found in Rea, Basov, Janecek, Palmer-Julson, et al. (1993). Profiles of sediment shear strength, wet and dry bulk density, water content, and porosity for Holes $881 \mathrm{C}, 883 \mathrm{~B}, 883 \mathrm{C}$, and $886 \mathrm{C}$ are presented in Figures 1-8. In general, the profiles exhibit the types of changes expected with increasing depth: decreasing water content, porosity, and void ratio values and increasing shear strength and density. The properties correlate well with lithologic variations, and a comparison of the index property profiles with the lithologic units (Shipboard Scientific Party, 1993a, 1993b, 1993c) shows that strong inflection points on the profiles occur at major lithologic boundaries. Variations contrary to the expected downcore trends reflect changing ratios of biogenic silica to terrigenous clay. The diatom oozes recovered at all three sites are characterized by low values for wet bulk density, dry bulk density, grain density, and shear strength and correspondingly high values for porosity and water content. The high porosities and water contents characteristic of the diatom oozes show little reduction with increasing sub-bottom depth. Similar observations have been reported for the diatom oozes of the Vøring Plateau (Pittenger et al., 1989; Pittenger, 1992) and the Weddell Sea (Bryant and Rack, 1990).

The nature of the inflections present in the index property profiles provides insight into the nature (sharp or gradational) of the corresponding lithologic contacts. An example of this may be seen in the sharp inflection at the contact between Subunit IIIA, a calcareous diatom ooze, and Subunit IIIB, a nannofossil chalk (Figs. 3, 4). Similarly in Figure 8, the porosity and water content values in Unit I remain fairly constant with values averaging $80 \%$ and $190 \%$, respectively. In lithologic Unit II porosity and water content increase slightly coincident with a sharp decrease in dry-bulk density that is consistent with a lithology of $>90 \%$ biogenic silica. The top of Unit III is marked by a sharp decrease in porosity and water content and a sharp increase in wet and dry bulk density and grain density. The trend reflected in the index property profiles suggests a gradational contact between Units I and II and a sharp contact between Units II and III.

The profiles of the ratio of vane shear strength to the effective overburden $\left(S_{u} / P_{o}^{\prime}\right)$ vs. depth presented in Figure 9 may be used to infer variations in the relative state-of-consolidation with depth (Skempton, 1970). Sediments with $S_{u} / P_{o}^{\prime}$ values that fall within the crosshatched region $\left(S_{u} / P_{o}^{\prime}=0.2\right.$ to 0.5$)$ are normally consolidated whereas sediments with values less than 0.2 are underconsolidated and greater than 0.5 are characteristic of overconsolidated sediments. The profiles for Holes $886 \mathrm{~B}$ and $886 \mathrm{C}$ are typical of normally consolidated marine sediments. The upper $10 \mathrm{mbsf}$ of the section in all three holes seems to be overconsolidated. However, this apparent overconsolidation of the uppermost portion of the sediment column is actually a reflection of the disparity between the magnitude of the intrinsic sediment shear strength, due to cohesion in the case of clays or to the interlocking of particles in the case of biogenic oozes, sands, or silts, and the low effective overburden stress (zero at the sediment/ water interface) in this zone. As a result, inferences regarding stateof-consolidation in the upper several meters of the sediment column based on the $S_{u} / P_{o}^{\prime}$ vs. depth profile must be made with caution. The $S_{u} / P_{o}^{\prime}$ profile for Hole $885 \mathrm{~A}$ reveals two zones of overconsolidated sediment, one from 13 to $17 \mathrm{mbsf}$ and another from 20 to $51 \mathrm{mbsf}$. Figure 10 presents a correlation of the GRAPE records from Holes $885 \mathrm{~A}, 886 \mathrm{~B}$, and $886 \mathrm{C}$ and a composite section (see Dickens et al., this volume). Lines on the figure show the correlation. A missing section occurs at approximately 19-20 mbsf in Hole 885A. A comparison of the radiolarian biostratigraphy in Holes $885 \mathrm{~A}$ and $886 \mathrm{C}$ suggests a missing section in Hole $885 \mathrm{~A}$ at approximately $13 \mathrm{mbsf}$ (J.J. Morley, pers. comm., 1994). The overconsolidated nature of the sediment below 13 mbsf suggests that a hiatus at this depth is the result of an erosional episode. Unfortunately, the lack of consolidation test data for Hole $885 \mathrm{~A}$ precludes further substantiation of the proposed erosional event and assessment of the amount of overburden removed.

\section{Consolidation Testing}

Six samples from Hole $886 \mathrm{C}$, three samples from Hole $881 \mathrm{C}$, and three samples from Hole $883 \mathrm{~B}$ were selected for consolidation testing. Each of these samples was selected to represent the suite of sediments recovered during Leg 145 . Sediment types include spicule clay, diatom ooze with clay, diatom ooze, clay, red clay, clayey diatom ooze, and clay with diatoms. The results of the consolidation tests are summarized in Table 2. Additional consolidation test results from the upper section of Hole 883B are presented in Roberts et al. (this volume). OCR values for all of the tests fall within the range of normally consolidated to slightly overconsolidated. Values for $c_{v}, m_{v}$, and permeability are reported for loads approximating the in situ effective overburden. All of the consolidation samples had high to very high initial void ratios ( $e_{0}=1.8$ to 4.1 ), which contribute to the mediumto high-volume compressibility values $\left(m_{v}=0.13\right.$ to $\left.2.22 \mathrm{~m}^{2} / \mathrm{MN}\right)$ observed. The $c_{y}$ values reported are typical of low plasticity clays or silts except for the values for the Unit III clays from Hole 886C which had $c_{y}$ values characteristic of a medium plasticity clay. The permeability values calculated from the $c_{v}$ data range from a high of $10^{-8}$ $\mathrm{m} / \mathrm{s}$ for diatom-rich sediment to a low of $10^{-10} \mathrm{~m} / \mathrm{s}$ for the red clay sample. The calculated values are significantly (two orders of magnitude) lower than values obtained from the falling-head permeability test. This result is contrary to expectations based on the high initial 


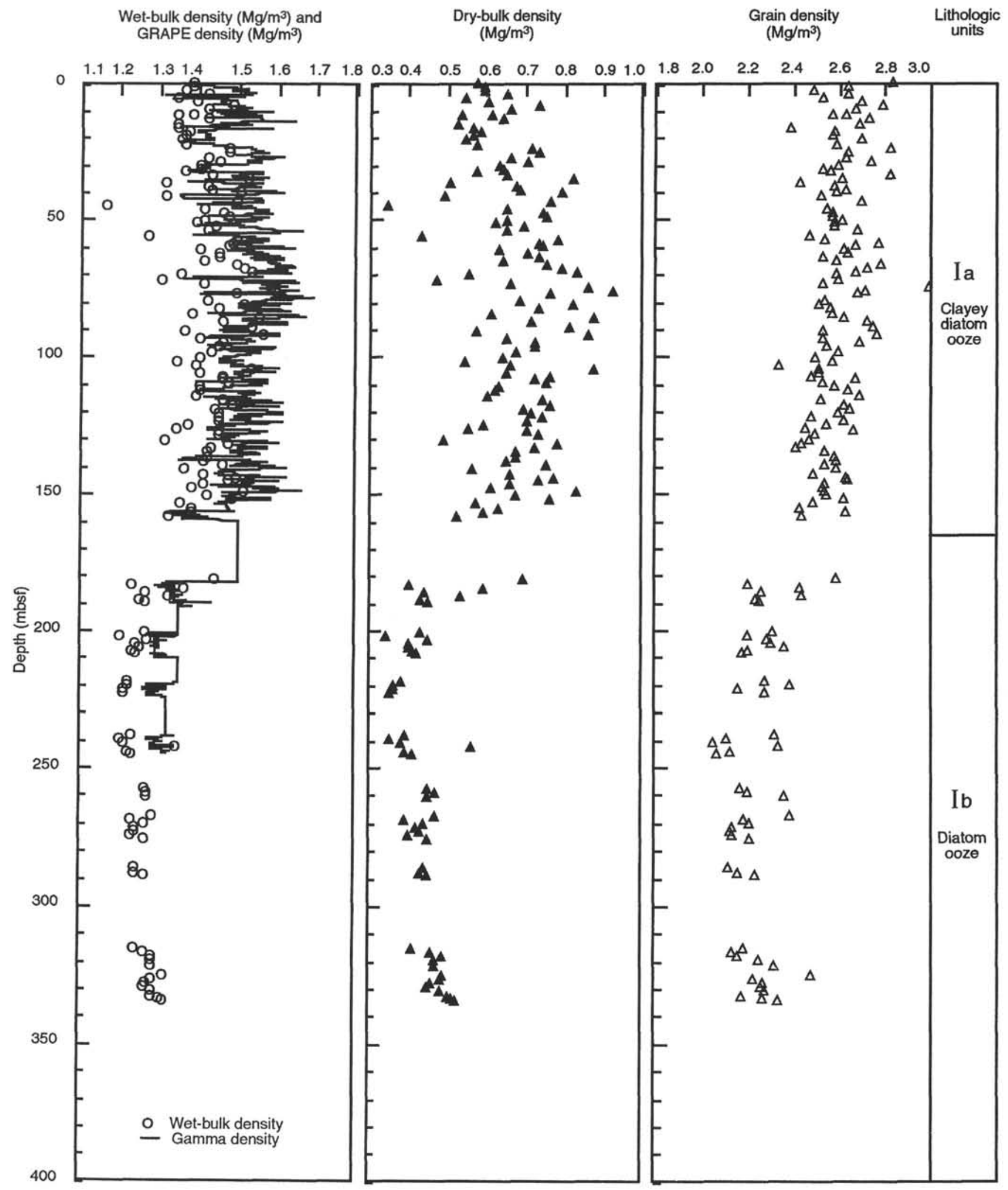

Figure 1. Wet bulk density, GRAPE density, dry bulk density, and grain density profiles for Hole 881C. 


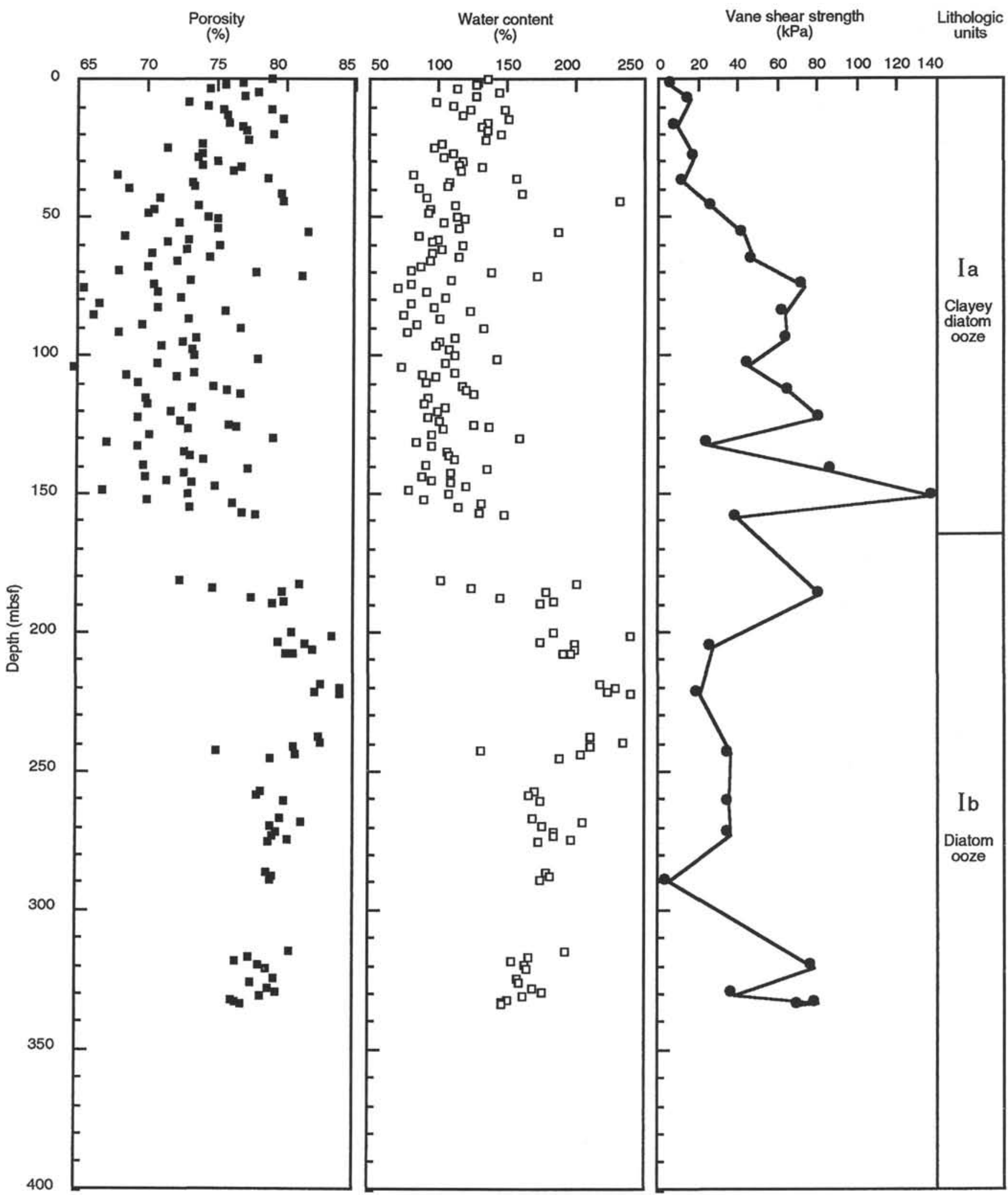

Figure 2. Porosity, water content, and vane shear strength profiles for Hole 881C.

compaction seen in the time-compression curves. Time-compression curves of this nature are characteristic of partly saturated sediments that would be expected to exhibit low measured permeability as a result of air impeding flow through the pores. Taylor (1984) suggested that high falling-head permeability values might be an artifact of an increased drainage rate due to seepage-induced consolidation.
Pittenger et al. (1989) reported permeability results with a single order of magnitude difference between calculated and measured values for diatom oozes of the Vøring Plateau. Pittenger's findings suggest that permeability results of this nature are characteristic of sediments with a biogenic silica component. We think that a leak in the oedometer is the most likely explanation for our anomalous values. 


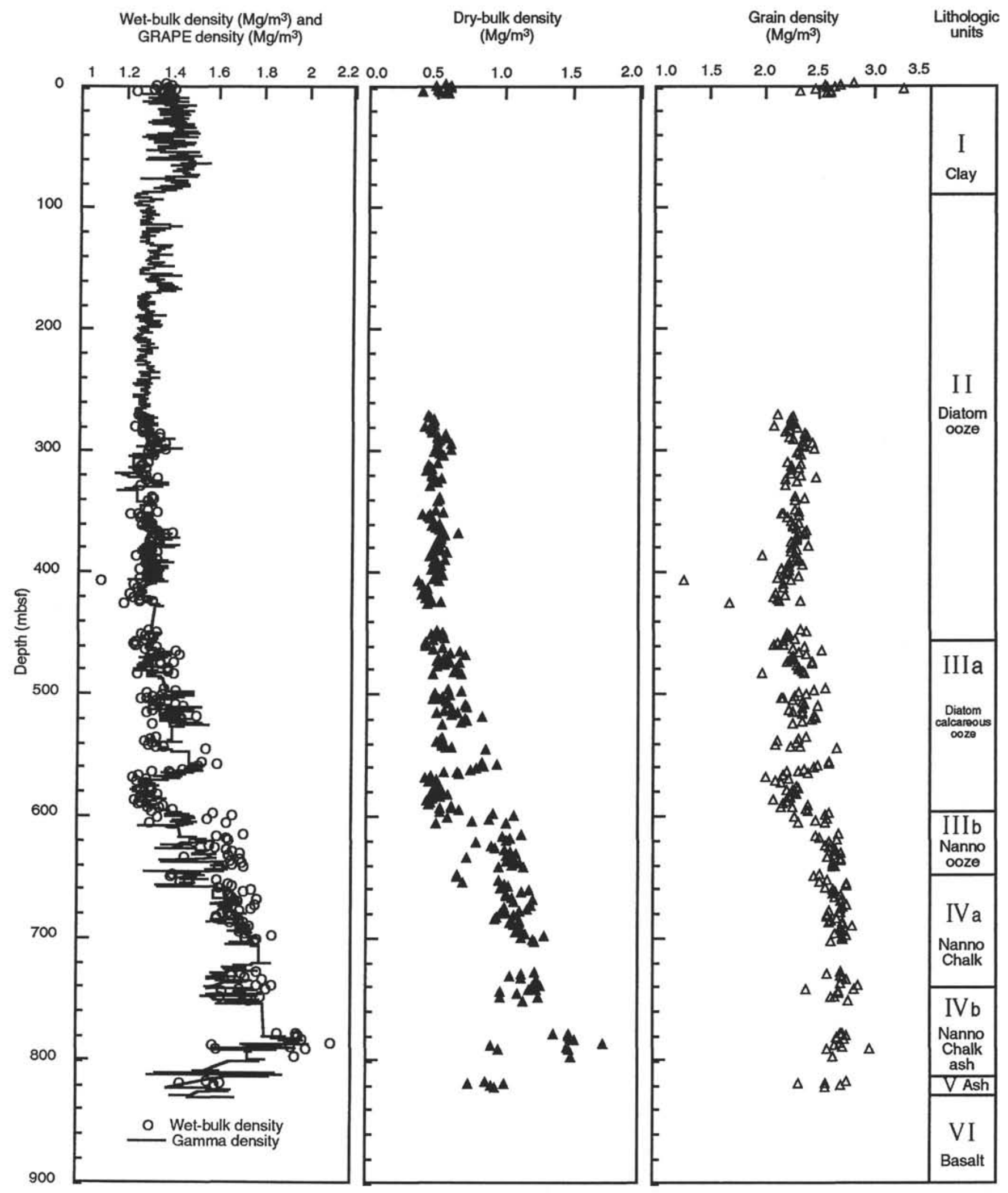

Figure 3. Wet bulk density, GRAPE density, dry bulk density, and grain density profiles for Holes 883B. 


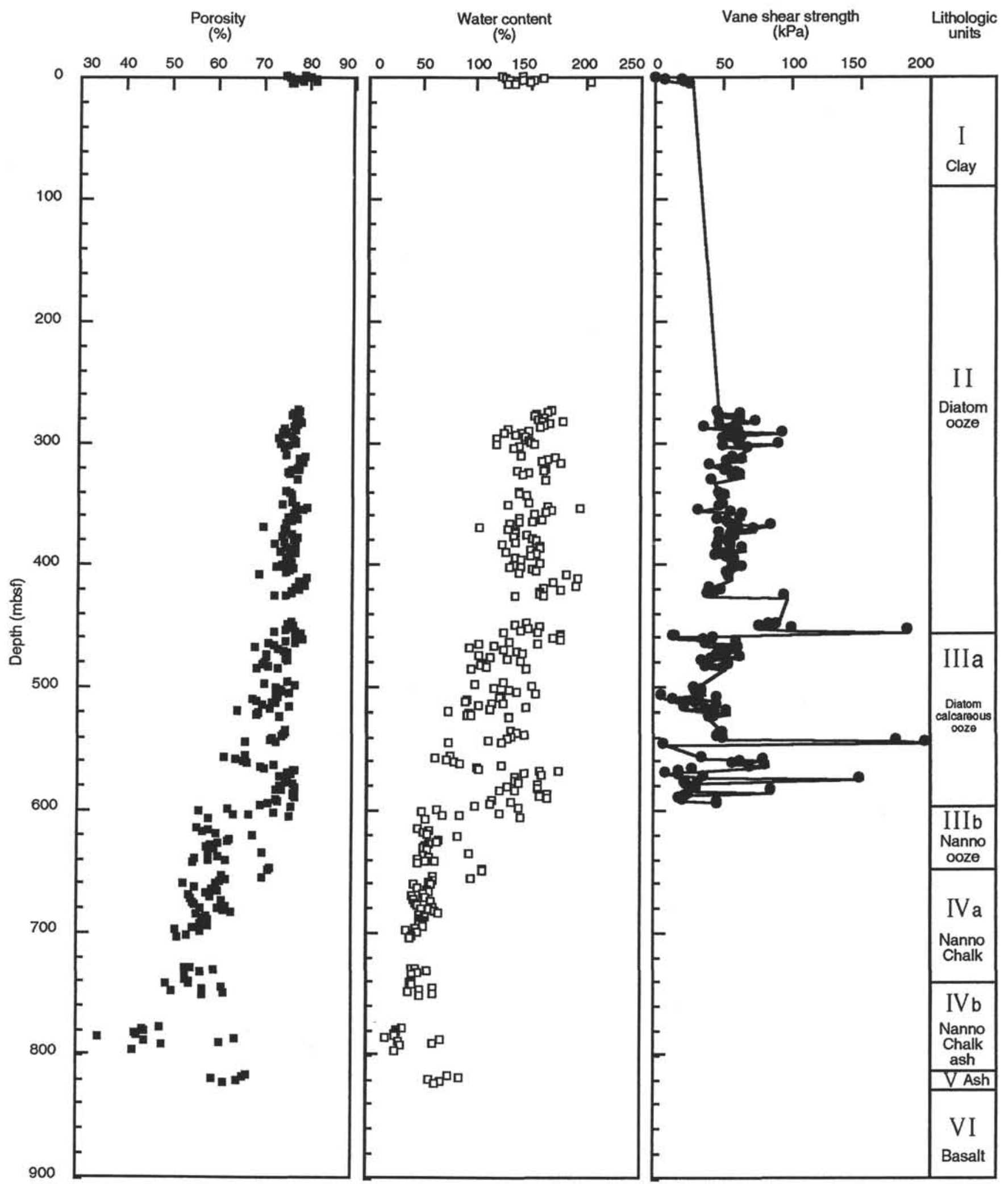

Figure 4. Porosity, water content, and vane shear strength profiles for Holes 883B.

The $e$ - $\log P^{\prime}$ curves for the tests conducted during this study are typical of marine sediments (Figs. 11, 12). The high initial void ratios may be attributed to the high percentage of diatoms present in all of the samples except for the three clays (Shipboard Scientific Party, 1993a, $1993 \mathrm{~b}, 1993 \mathrm{c})$. It is interesting to note the almost identical nature (curve shape and range of void ratio values) of the $e-\log P^{\prime}$ curves in
Figures $11 \mathrm{~F}$ and $12 \mathrm{~F}$. Based on this comparison, the samples might be assumed to be of similar sediment types with similar stress histories. They are, in fact, very different. The curve in Figure $11 \mathrm{~F}$ is for a clay recovered from a depth of $71.2 \mathrm{mbsf}$, whereas the sample represented in Figure $12 \mathrm{~F}$ is a diatom ooze ( $80 \%$ diatoms) with clay and calcite recovered from a depth of $456.1 \mathrm{mbsf}$. This suggests that sediments 


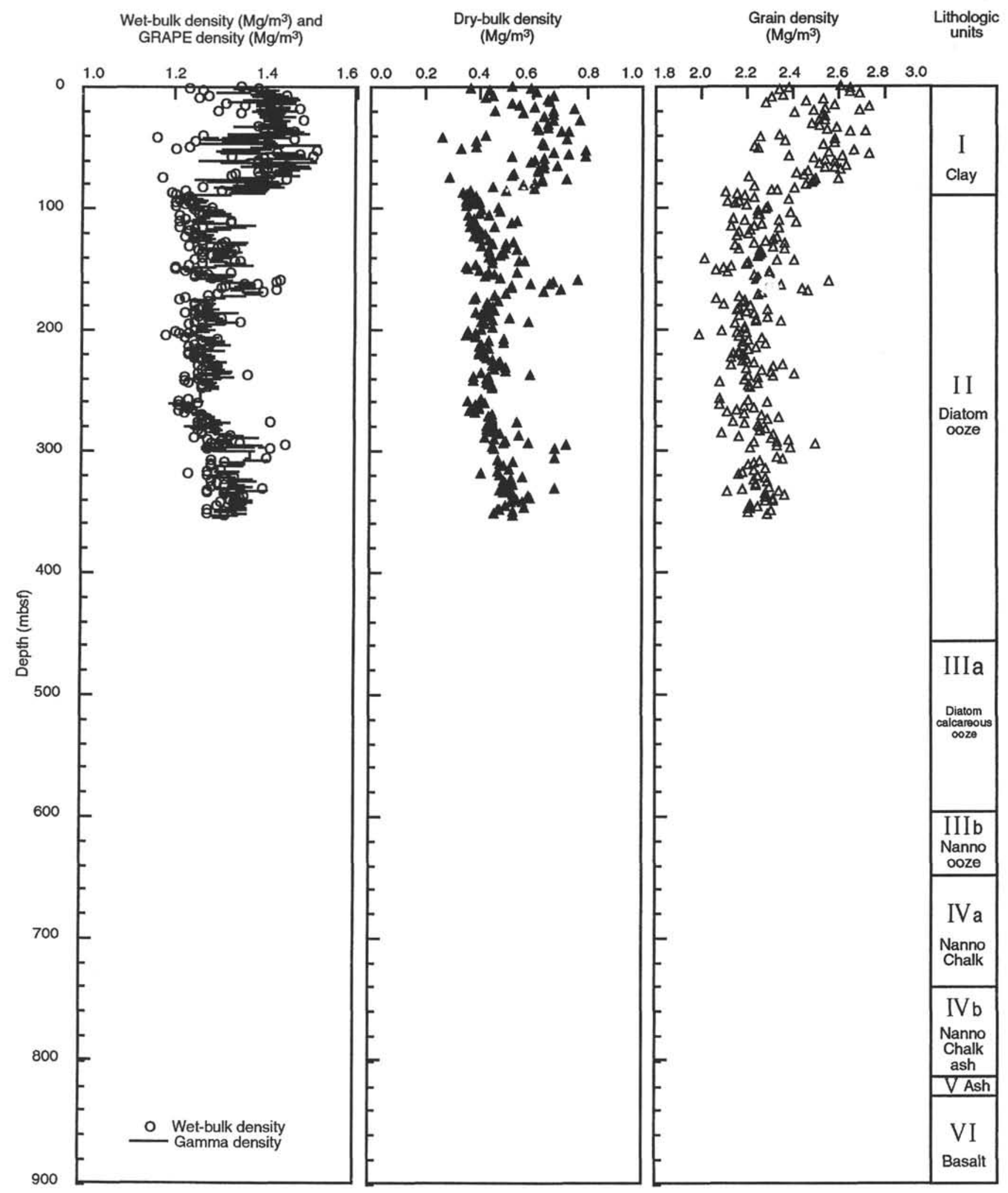

Figure 5 . Wet bulk density, GRAPE density, dry bulk density, and grain density profiles for Hole $883 \mathrm{C}$. 


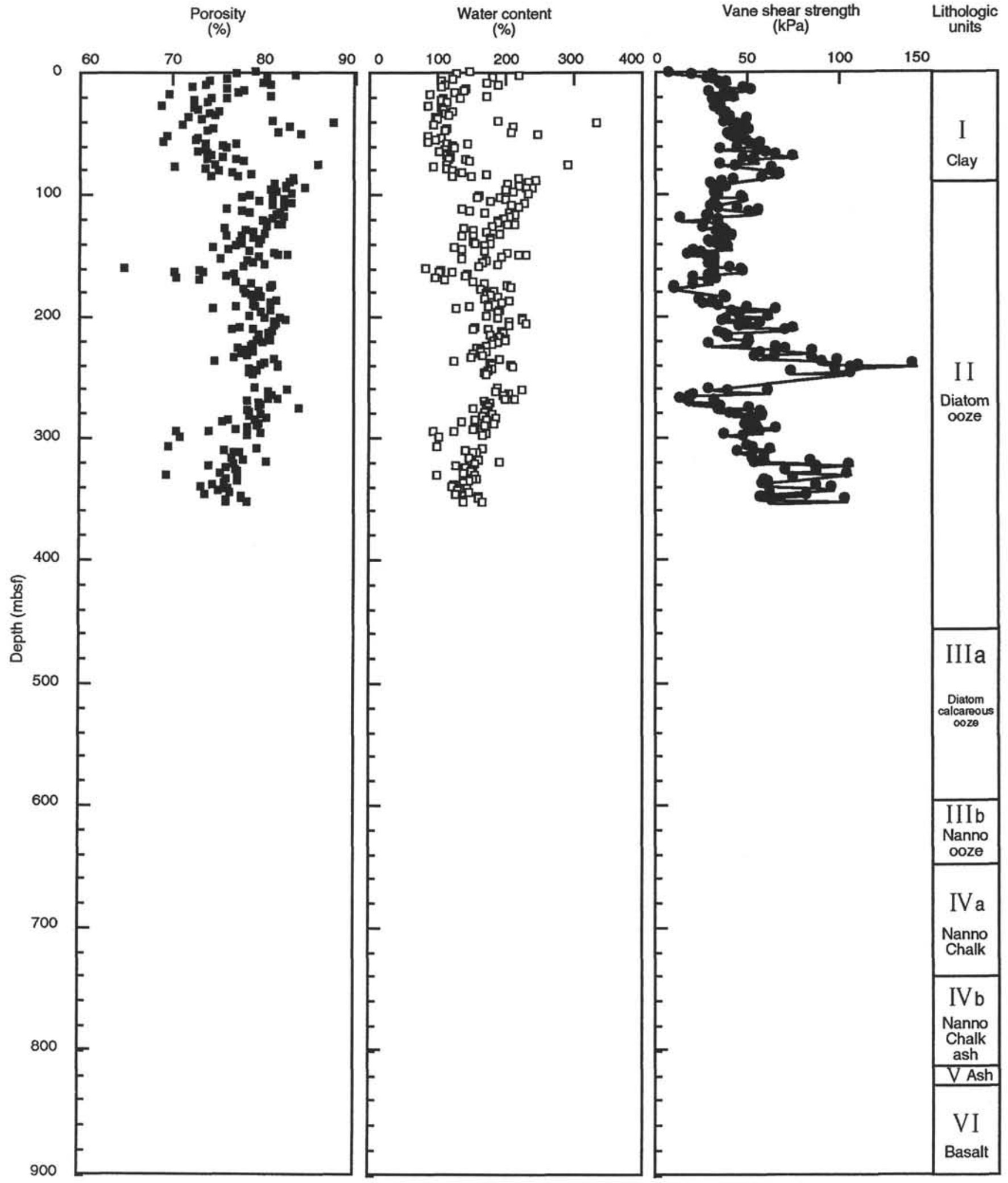

Figure 6. Porosity, water content, and vane shear strength profiles for Hole 883C. 


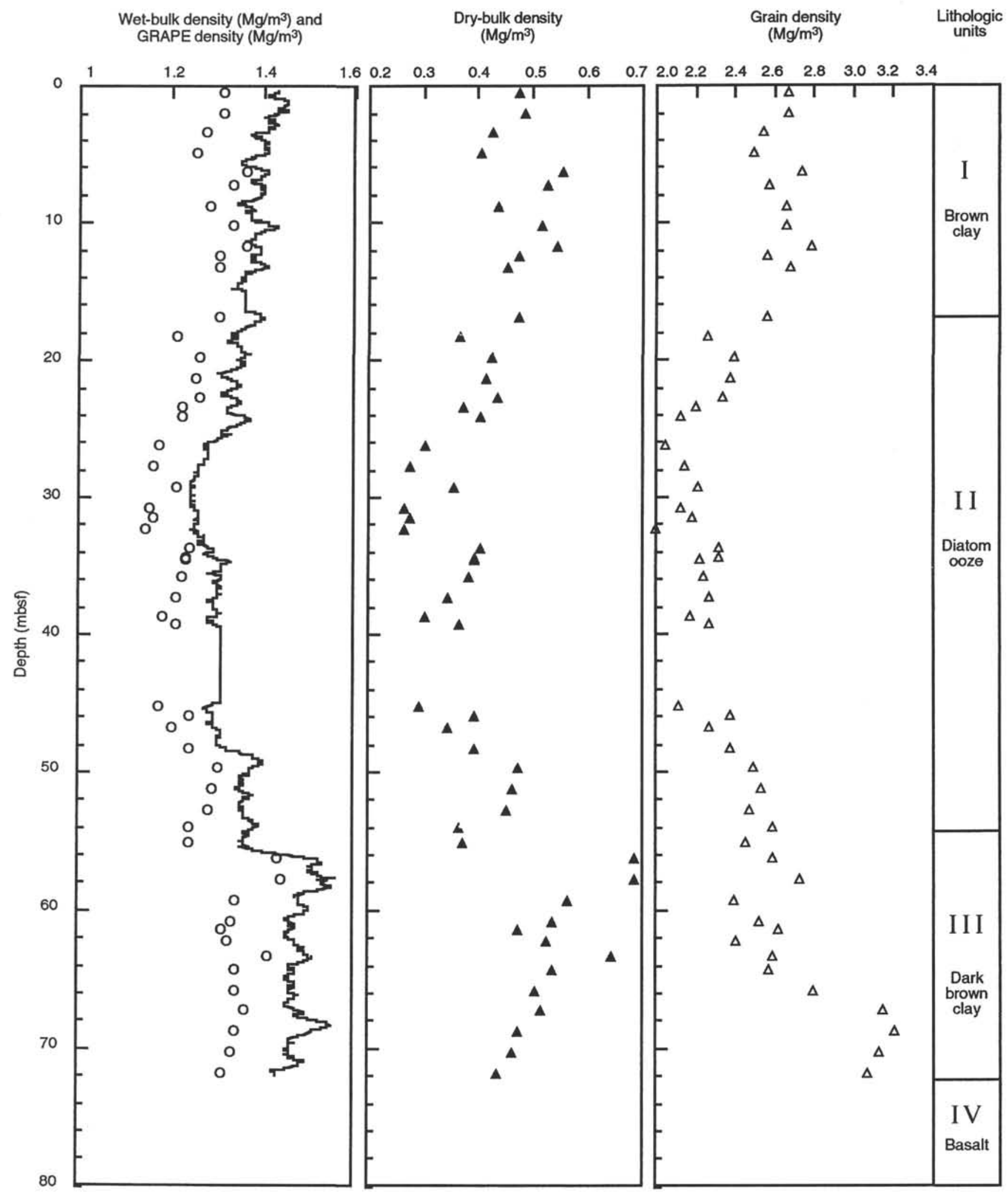

Figure 7. Wet bulk density, GRAPE density, dry bulk density, and grain density profiles for Hole 886C. 


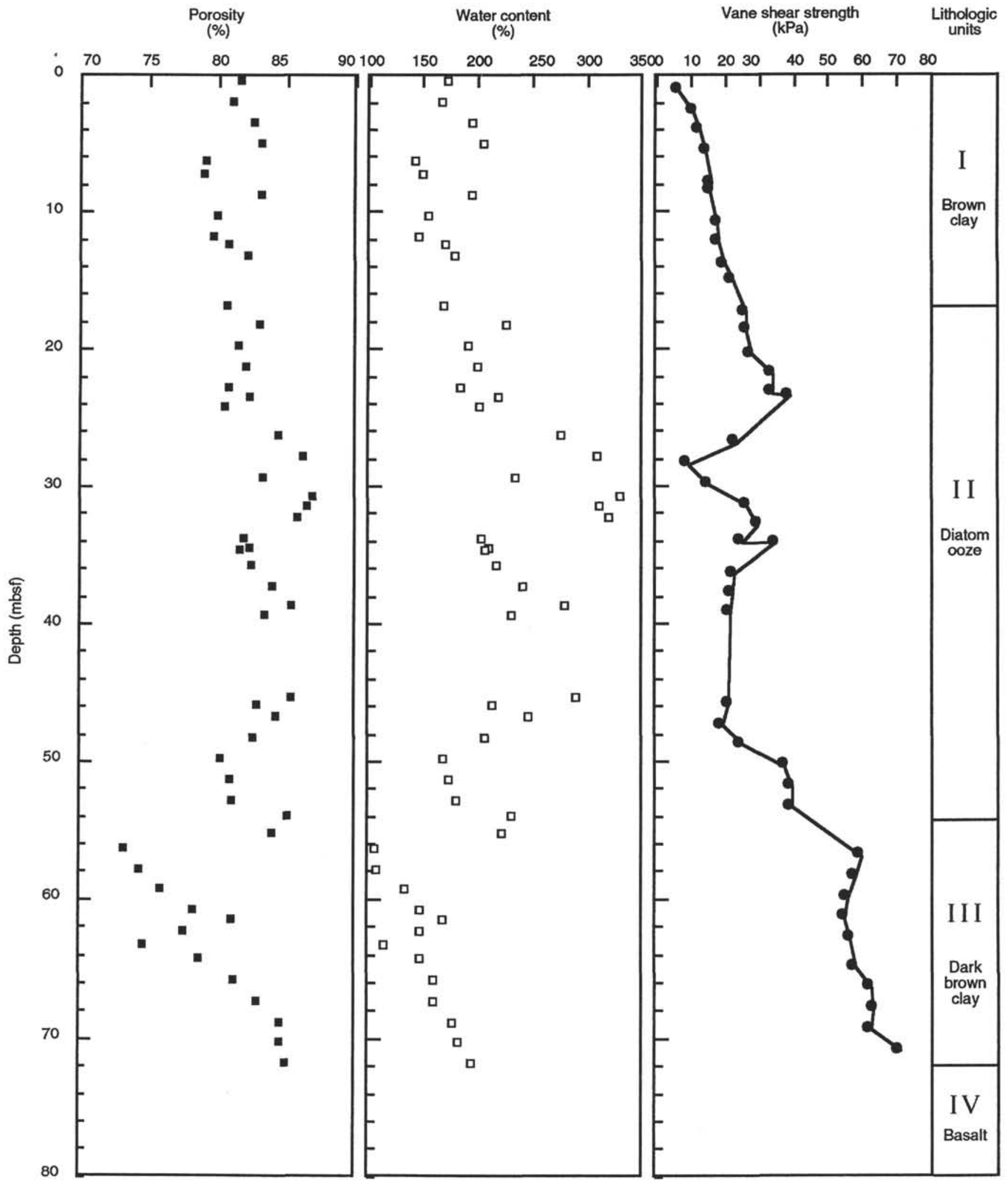

Figure 8. Porosity, water content, and vane shear strength profiles for Hole 886C.

with a significant diatom component do not experience the magnitude volume change in situ that laboratory consolidation tests predict. Comparison of the field consolidation curves in Figure 13 with the $e$ - $\log P^{\prime}$ curves provides further confirmation of this observation. The bold vertical lines on the field curves mark the top of a diatomrich interval. In every case the void ratio increases sharply at the contact between the diatom-rich interval and the overlying clay-rich interval. In Figures 13B and 13D, the vertical dashed lines mark the bottom of the diatom-rich interval. A rapid reduction of void ratio occurs below this point similar to that seen in laboratory consolidation tests. The porosity profiles (Figs. 2, 4, 6, 8) also support the premise that little in situ consolidation occurs in diatomaceous sedi- 
Table 2. Consolidation results for samples from Sites $\mathbf{8 8 1}, \mathbf{8 8 3}$, and 885/886.

\begin{tabular}{|c|c|c|c|c|c|c|c|c|c|}
\hline $\begin{array}{l}\text { Core, section, } \\
\text { interval }(\mathrm{cm})\end{array}$ & $\begin{array}{l}\text { Depth } \\
\text { (mbsf) }\end{array}$ & Sediment type & $\begin{array}{c}\text { CT } \\
\text { scanned? }\end{array}$ & $\begin{array}{c}P_{e}^{\prime} \\
(\mathrm{kPa})\end{array}$ & $\begin{array}{c}P_{c}^{\prime} \\
(\mathrm{kPa})\end{array}$ & OCR & $\begin{array}{c}C_{y} \\
\left(\mathrm{~m}^{2} / \mathrm{yr}\right)\end{array}$ & $\begin{array}{c}m_{v} \\
\left(\mathrm{~m}^{2} / \mathrm{MN}\right)\end{array}$ & $\begin{array}{c}\text { Calculated } \\
\text { permeability } \\
(\mathrm{m} / \mathrm{s})\end{array}$ \\
\hline \multicolumn{10}{|l|}{$145-886 \mathrm{C}$} \\
\hline $2 \mathrm{H}-4,140-150$ & 12.7 & Spicule clay & Yes & 36.6 & 42 & 1 & 30.78 & 2.22 & 1.19E-08 \\
\hline $3 \mathrm{H}-5,140-150$ & 23.7 & Diatom ooze with clay & Yes & 62.0 & 140 & 2 & 105.53 & 0.59 & $1.40 \mathrm{E}-08$ \\
\hline $4 \mathrm{H}-4,138-150$ & 31.7 & Diatom ooze & Yes & 77.3 & 180 & 2 & 100.48 & 0.46 & $1.50 \mathrm{E}-08$ \\
\hline $6 \mathrm{H}-1,140-150$ & 46.2 & Diatom ooze with clay & No & 100.0 & 205 & 2 & 102.41 & 0.44 & $1.47 \mathrm{E}-08$ \\
\hline $7 \mathrm{H}-5,138-150$ & 61.7 & Clay & No & 143.0 & 225 & 2 & 1.19 & 0.67 & $2.78 \mathrm{E}-10$ \\
\hline $8 \mathrm{H}-5,138-150$ & 71.2 & Red clay & Yes & 174.0 & 230 & $i$ & 5.85 & 0.35 & $3.76 \mathrm{E}-10$ \\
\hline \multicolumn{10}{|l|}{$145-881 \mathrm{C}$} \\
\hline $3 \mathrm{H}-4,138-150$ & 19.2 & Clayey diatom ooze & No & 68.4 & 69 & 1 & 10.97 & 1.00 & $1.79 \mathrm{E}-09$ \\
\hline $12 \mathrm{H}-3,138-150$ & 103.2 & Clayey diatom ooze & No & 411.4 & 660 & 2 & 48.11 & 0.14 & $1.05 \mathrm{E}-09$ \\
\hline $21 \mathrm{H}-5,138-150$ & 189.1 & Diatom ooze & No & 696.8 & 620 & $\overrightarrow{1}$ & 83.75 & 0.13 & 3.40E-09 \\
\hline \multicolumn{10}{|l|}{ 145-883B- } \\
\hline $6 \mathrm{H}-5,138-150$ & 53.3 & Clay with diatoms & No & 180.4 & 310 & 2 & 78.68 & 0.40 & $9.77 \mathrm{E}-09$ \\
\hline $10 \mathrm{H}-2,138-150 \mathrm{~cm}$ & 86.8 & Clayey diatom ooze & No & 268.3 & 290 & I & 57.88 & 0.21 & 3.82E-09 \\
\hline $48 \mathrm{X}-5,138-150 \mathrm{~cm}$ & 456.1 & Diatom ooze with clay and calcite & No & 1238.3 & 1000 & 1 & 85.82 & 0.10 & 2.65E-09 \\
\hline
\end{tabular}

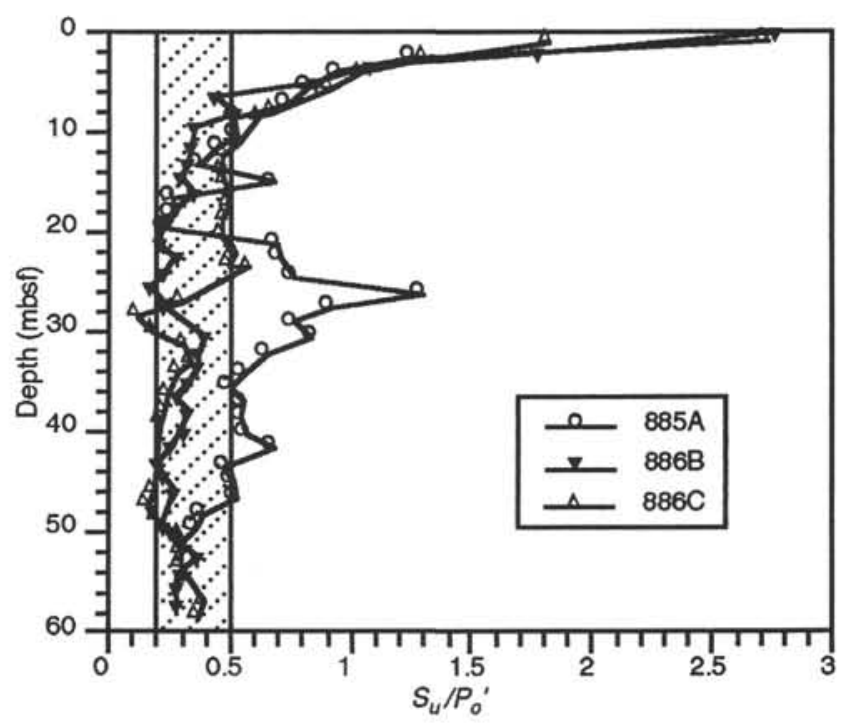

Figure 9. $S_{t} / P_{o}^{\prime}$ with depth for Holes $885 \mathrm{~A}, 886 \mathrm{~B}$, and $886 \mathrm{C}$, Values lying within the cross-hatched interval $\left(S_{t u} / P_{o}^{\prime}=0.2\right.$ to 0.5$)$ are normally consolidated.

ments. For example, the porosity profile for Hole $883 \mathrm{~B}$ (Fig. 4) reveals porosity values of $60 \%$ to $80 \%$ persisting to $600 \mathrm{mbsf}$. Pittenger (1992) attributed his similar findings to the structural strength of the diatom frustules.

\section{CT Scan Examination}

The four consolidation samples from Hole $886 \mathrm{C}$ that were CTscanned prior to consolidation testing are Samples $145-886 \mathrm{C}-2 \mathrm{H}-4$, $140-150 \mathrm{~cm} ;-3 \mathrm{H}-5,140-150 \mathrm{~cm} ;-4 \mathrm{H}-4,138-150 \mathrm{~cm}$; and $-8 \mathrm{H}-5$, $138-150 \mathrm{~cm}$. Plates 2 through 5 show representative CT images from near the center of each sample. Overall, these images demonstrate that the samples were essentially homogeneous (PI. 3, Fig. 2; Pl. 4, Fig. 1; Pl. 5, Fig. 2) because discernible structures were generally limited to indistinct horizontal to subhorizontal trace fossils. These burrow traces, ichnogenus Planolites (Chamberlain, 1975; Eckdale et al., 1984), were commonly characterized by low-density interiors in contrast with the surrounding matrix (PI. 2, Fig. 1); in other images, burrow infill appears to be of higher density material (Pl. 3, Fig. 1; Pl. 5, Fig. 1). The average cross-sectional diameter of both burrow types is approximately $5 \mathrm{~mm}$. The only other types of structures imaged are shown in Plate 2, Figure 2. Two faint halo burrows with diameters of $\sim 4 \mathrm{~mm}$ were observed to extend vertically over several centimeters with little apparent horizontal migration. The last structure was a large low-density feature (2-cm diameter) that migrates with depth in the sample (i.e., its orientation is oblique to the scan plane and hence moves from right to left in sequential CT images). This feature is apparently some sort of feeding structure created by an animal larger than those producing the other burrows.

Although CT image sequences of samples of uniform composition without distinct sedimentary structures are somewhat monotonous, they provide verification of Terzaghi's (1943) assumption of sediment homogeneity. Although it might be tempting to ascribe the apparent lack of significant structure in these samples as a failing (or at least a weakness) of CT, previous calibration experiments conducted on the Technicare $\Delta-100 \mathrm{CT}$ scanner found the density resolution (precision) of the machine to be $\sim 0.005 \mathrm{Mg} / \mathrm{m}^{3}$ (Orsi, 1994; Orsi et al., 1994). This precision is identical to that achieved by Been (1981) for an X-ray apparatus developed to measure vertical bulk density distributions within laboratory sedimentation columns. As stated by Been (1981), “...greater precision is not warranted [in his or in the present investigation] as densities measured to the fourth significant figure fluctuate with temperature variations."

\section{CONCLUSIONS}

The extensive set of physical property measurements made during Leg 145 provides further geotechnical characterization of the sediments of the North Pacific. This is particularly important in the case of the diatomaceous sediments recovered. Accurate interpretation of geotechnical test results depends upon the existence of a database comprising the accumulated results of previous tests for each type of sediment. The development of such a database for siliceous oozes has lagged behind that of other sediment types (i.e., terrigenous clays and calcareous oozes), but is progressing steadily. The results of this study should further serve to emphasize the need for continued study of the unique nature of diatomaceous sediments. The lack of in situ consolidation and the preservation of porosity of diatomaceous sediments has been demonstrated, although some question remains regarding the mechanism responsible for maintaining the downcore porosity. The $S_{u} / P_{o}^{\prime}$ profiles for Holes $885 \mathrm{~A}, 886 \mathrm{~B}$, and $886 \mathrm{C}$, in conjunction with correlations of the index properties and radiolarian biostratigraphy, indicate the presence of a hiatus in the upper section of Hole $885 \mathrm{~A}$. The overconsolidated nature of the sediment points to an erosional nature for the hiatus. This technique is a quick and easy way to assess the state of consolidation of a sediment column, and is a valuable supplement to consolidation test data.

Wet bulk density is a fundamental property of marine sediments related directly to the sedimentation history of the deposit. Considering its sensitivity to this property, CT has a number of other potential uses besides that shown here. For example, it would be very useful to make strategic CT images indexed to other ODP measurements, such as GRAPE, magnetic susceptibility, velocity, etc., to achieve a better 


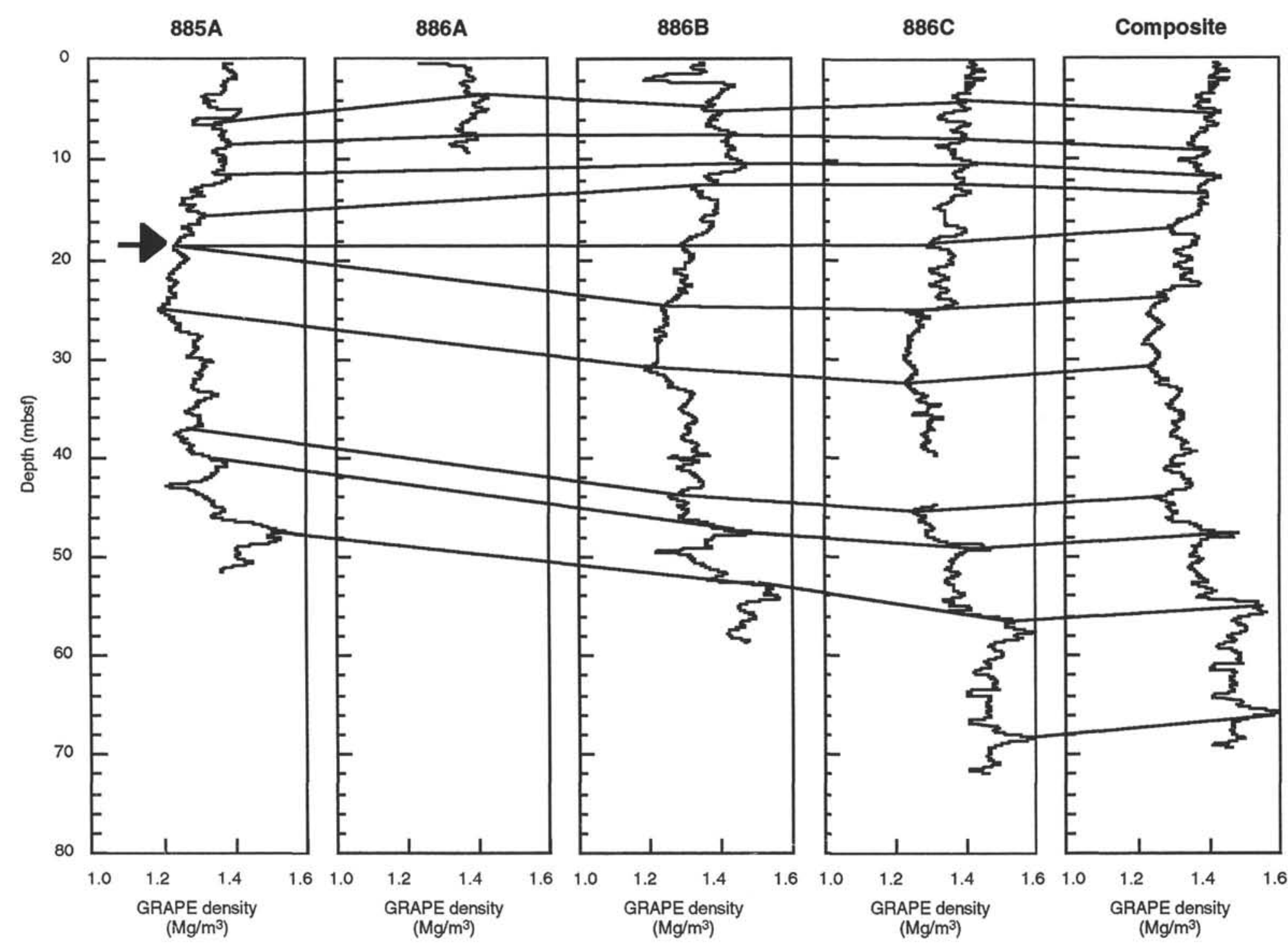

Figure 10. Correlation of GRAPE density profiles at Site 885/886. The arrow on the profile from Hole 885A marks the missing section. 

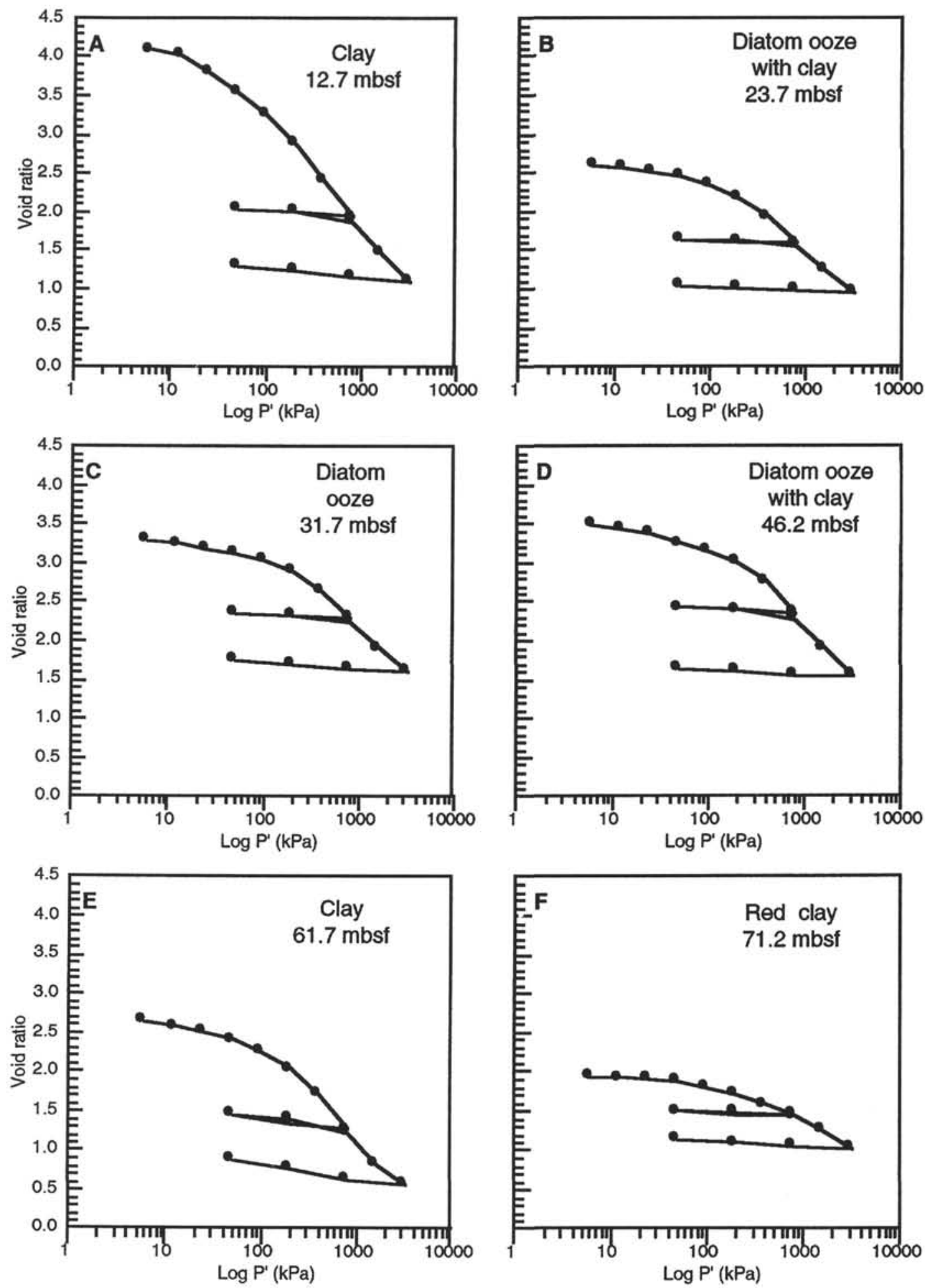

Figure 11. Consolidation test results: $e$-Log $P^{\prime}$ plots for consolidation samples. A. Sample 145-886C-2H-4, 140-150 cm. B. Sample 145-886C-3H-5, 140-150 cm. C. Sample $145-886$ C-4H-4, 138-150 cm. D. $145-886$ C-6H-1, 140-150 cm. E. $145-886$ C-7H-5, 138-150 cm. F. Sample 145-886C-8H-5, 138-150 cm.

understanding of physical property characteristics and sediment variability. In addition, sediment depth profiles of CT density can be generated by averaging values over a fixed region-of-interest within each CT image. These profiles are similar to those produced by the GRAPE system, although the "slab" of material integrated in CT differs from the cylindrical volume used for the GRAPE measurements. Importantly, the determination of the standard deviation of the CT image is crucial in studies of sediment heterogeneity.

\section{ACKNOWLEDGMENTS}

Our participation on Leg 145 was made possible by funding from USSAC (Rutledge, Orsi, and Bryant), ONR-NDSEG (Rutledge and Orsi), NERC and SERC (Roberts), and ESF (Kotilainen). We thank Dr. Wayne Dunlap for the use of the TAMU Department of Civil Engineering Consolidation Labs. Finally, we thank Dr. C.M. Edwards, Director of the Engineering Imaging Center of the Texas Engineering 
Experiment Station, for his helpful suggestions during the CT portion of this study.

\section{REFERENCES}

Anderson, S.H., Gantzer, C.J., Boone, J.M., and Tully, R.J., 1988. Rapid nondestructive bulk density and soil-water content determination by computed tomography. Soil Sci. Soc. Am. J., 52:35-40.

Been, K., 1981. Nondestructive soil bulk density measurements by x-ray attenuation. Geotech. Test. J., 4:169-176.

Bennett, R.H., and Nelsen, T.A., 1983. Seafloor characteristics and dynamics affecting geotechnical properties at shelfbreaks. In Stanley, D.J., and Moore, G.T. (Eds.), The Shelf Break: Critical Interface on Continental Margins. Spec. Publ.-Soc. Econ. Paleontol. Mineral., 33:333-355.

Boyce, R.E., 1976. Definitions and laboratory techniques of compressional sound velocity parameters and wet-water content, wet-bulk density, and porosity parameters by gravimetric and gamma ray attenuation techniques. In Schlanger, S.O., Jackson, E.D., et al., Init. Repts. DSDP, 33: Washington (U.S. Govt. Printing Office), 931-958.

Brooks, R.A., and Di Chiro, G., 1975. Theory of image reconstruction in computed tomography. Radiology, 117:561-572.

Bryant, W.R., Bennett, R.H., and Katherman, C.E., 1981. Shear strength, consolidation, porosity, and permeability of oceanic sediments. In Emiliani, C. (Ed.), The Sea (Vol. 7): The Oceanic Lithosphere: New York (Wiley), 1555-1616.

Bryant, W.R., Deflache, A.P., and Trabant, P.K., 1974. Consolidation of marine clays and carbonates. In Inderbitzen, A.L. (Ed.), Deep-Sea Sediments: Physical and Mechanical Properties (1st ed.): New York (Plenum), 209244.

Bryant, W.R., and Rack, F.R., 1990. Consolidation characteristics of Weddell Sea sediments: results of ODP Leg 113. In Barker, P.F., Kennett, J.P., et al., Proc. ODP, Sci. Results, 113: College Station, TX (Ocean Drilling Program), 211-223.

Casagrande, A., 1936. The determination of preconsolidation load and its practical significance. Proc. Ist Int. Conf. Soil Mech. and Foundation Eng., Am. Soc. Civ. Eng., 3:60-64.

Chamberlain, C.K., 1975. Trace fossils in DSDP cores of the Pacific. $J$. Paleontol., 49:1074-1096.

Eckdale, A.A., Muller, L.N., and Novak, M.T., 1984. Quantitative ichnology of modern pelagic deposits in the abyssal Atlantic. Palaeogeogr., Palaeoclimatol., Palaeoecol., 45:189-223.

Evans, H.B., 1965. GRAPE-a device for continuous determination of material density and porosity. Trans. SPWLA 6th Annu. Logging Symp., Dallas, 2:B1-B25.

Folk, R.L., 1974. Petrology of Sedimentary Rocks: Austin, TX (Hemphill Publ.).

Head, K.H., 1988. Manual of Soil Laboratory Testing (Vol. 2) (2nd ed.): London (Pentech Press).

Hounsfield, G.N., 1973. Computerized transverse axial scanning (tomography): Part I. Description of system. Br. J. Radiol., 46:1016-1022.

Keller, G.H., 1974. Marine geotechnical properties: interrelationships and relationships to depth of burial. In Inderbitzen, A.L. (Ed.), Deep-Sea Sediments: Physical and Mechanical Properties (1st ed.): New York (Plenum Press), 77-100.
McCullough, E.C., 1975. Photon attenuation in computed tomography. Med. Phys., 2:307-320.

Moran, K., 1993. Notice to users of GRAPE data. JOIDES J., 19:6.

Orsi, T.H., 1994. Computed tomography and physical property variability of seafloor sediments [Ph.D. thesis]. Texas A\&M Univ., College Station.

Orsi, T.H., Anderson, A.L., Leonard, J.N., Bryant, W.R., and Edwards, C.M., 1992. Use of X-ray computed tomography in the study of marine sediments. Proc. Int. Conf. Civ. Eng. Oceans, 968-981.

Orsi, T.H., Edwards, C.M., and Anderson, A.L., 1994. X-ray computed tomography: a nondestructive method for quantitative analysis of sediment cores. J. Sediment. Res., A64:690-693.

Petrovic, A.M., Siebert, J.E., and Rieke, P.E., 1982. Soil bulk density analysis in three dimensions by computed tomographic scanning. Soil Sci. Soc. Am. J., 46:445-450.

Pittenger, A., 1992. Geotechnical properties of siliceous sediments from the Vøring Plateau, Southern Ocean [Ph.D. thesis]. Texas A\&M Univ., College Station.

Pittenger, A., Taylor, E., and Bryant, W.R., 1989. The influence of biogenic silica on the geotechnical stratigraphy of the Vøring Plateau, Norwegian Sea. In Eldholm, O., Thiede, J., Taylor, E., et al., Proc. ODP, Sci. Results, 104: College Station, TX (Ocean Drilling Program), 923-940.

Rea, D.K., Basov, I.A., Janecek, T.R., Palmer-Julson, A., et al., 1993. Proc. ODP, Init. Repts., 145: College Station, TX (Ocean Drilling Program).

Shipboard Scientific Party, 1993a. Site 881. In Rea, D.K., Basov, I.A., Janecek, T.R., Palmer-Julson, A., et al., Proc. ODP, Init. Repts., 145: College Station, TX (Ocean Drilling Program), 37-83.

, 1993b. Site 883. In Rea, D.K., Basov, I.A., Janecek, T.R., PalmerJulson, A., et al., Proc. ODP, Init. Repts., 145: College Station, TX (Ocean Drilling Program), 121-208.

, 1993c. Sites 885/886. In Rea, D.K., Basov, I.A., Janecek, T.R., Palmer-Julson, A., et al., Proc. ODP, Init. Repts., 145: College Station, TX (Ocean Drilling Program), 303-334.

Skempton, A.W., 1970. The consolidation of clays by gravitational compaction. Q. J. Geol. Soc. London, 125:373-411.

Taylor, E., 1984. Oceanic sedimentation and geotechnical stratigraphy: hemipelagic carbonates and red clays [Ph.D. dissert.]. Texas A\&M Univ., College Station.

Terzaghi, K., 1943. Theoretical Soil Mechanics: New York (Wiley).

Vinegar, H.J., and Wellington, S.L., 1987. Tomographic imaging of threephase flow experiments. Rev. Sci. Instrum., 58:96-107.

Warner, G.S., Neiber, J.L., Moore, I.D., and Geise, R.A., 1989. Characterizing macropores in soil by computed tomography. Soil Sci. Soc. Am. J., 53:653660 .

\footnotetext{
- Abbreviations for names of organizations and publications in ODP reference lists follow the style given in Chemical Abstracts Service Source Index (published by American Chemical Society).
}

Date of initial receipt: 30 March 1994

Date of acceptance: 12 September 1994

Ms 145SR-141 

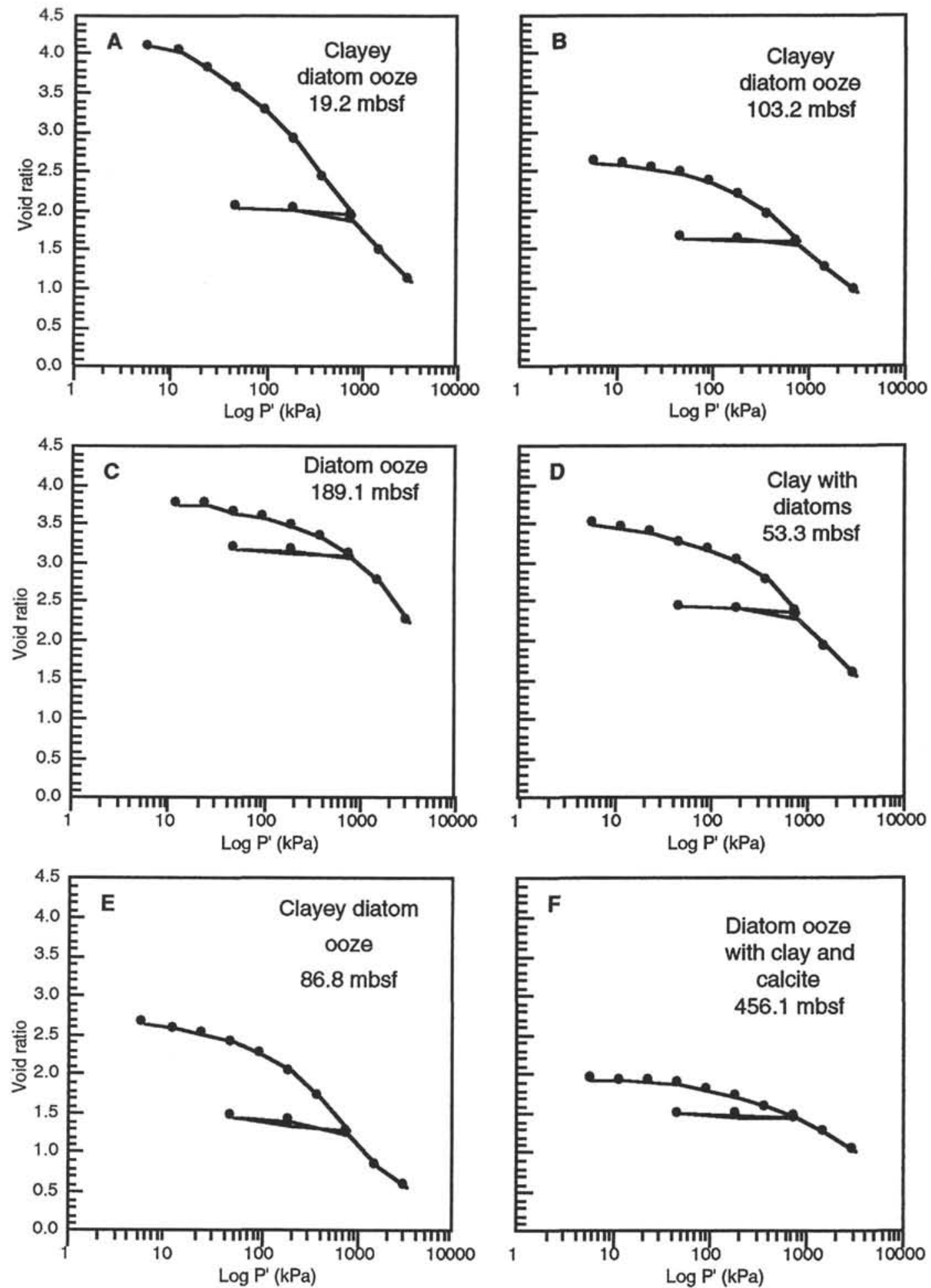

Figure 12. Consolidation test results: $e$-Log $P^{\prime}$ plots for consolidation samples. A. Sample 145-881C-3H-4, 138-150 cm. B. Sample 145-881C-12H-3, 138-150 cm. C. Sample $145-881$ C-21H-5, 138-150 cm. D. Sample 145-883B-6H-5, 138-150 cm. E. Sample $145-883 B-10 H-2,138-150 \mathrm{~cm}$. F. Sample 145-883B-48X-5, $138-150 \mathrm{~cm}$. 

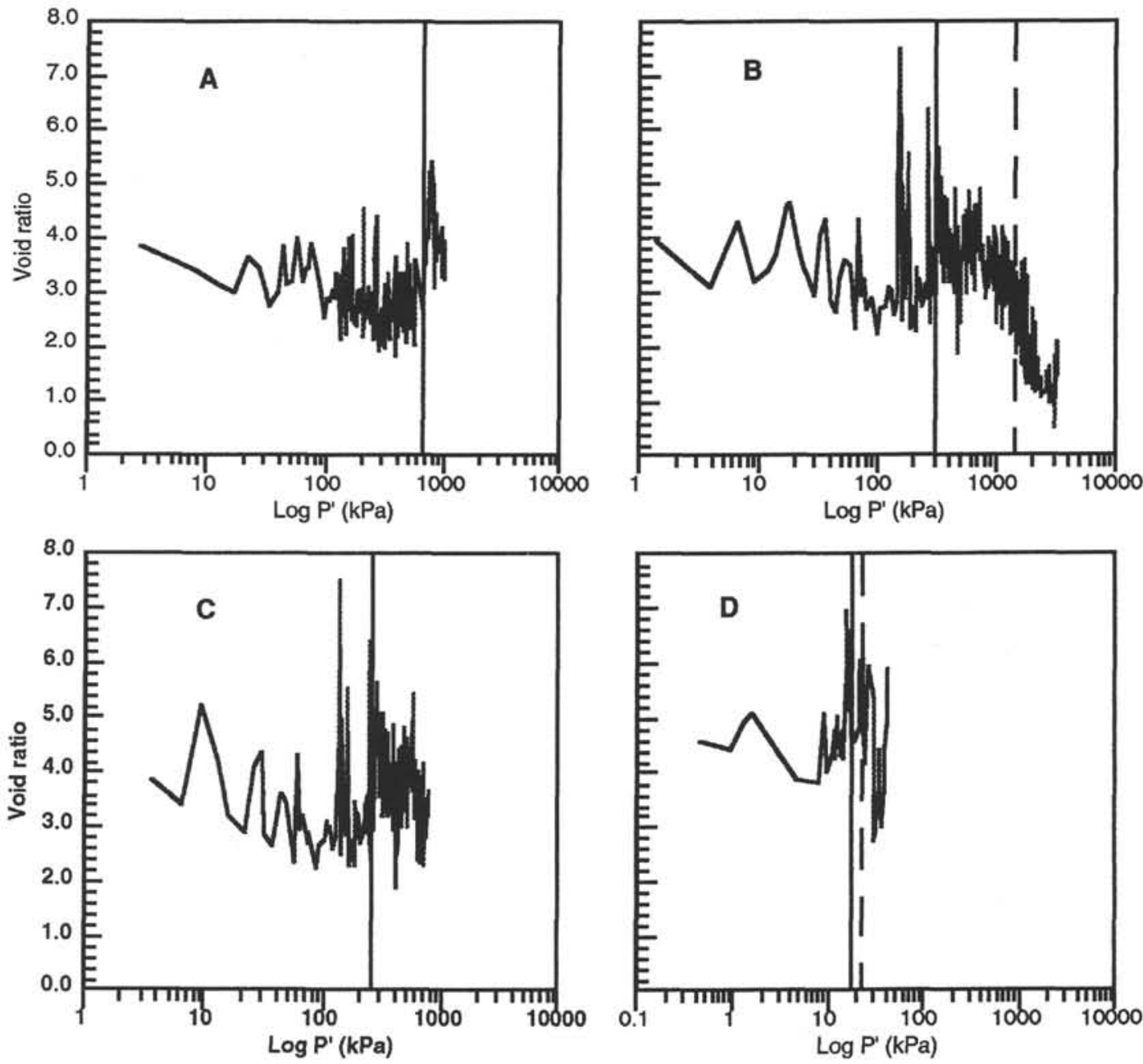

Figure 13. Field consolidation curves for (A) Hole 881C, (B) Hole 883B, (C) Hole 883C, and (D) Hole 886C. 


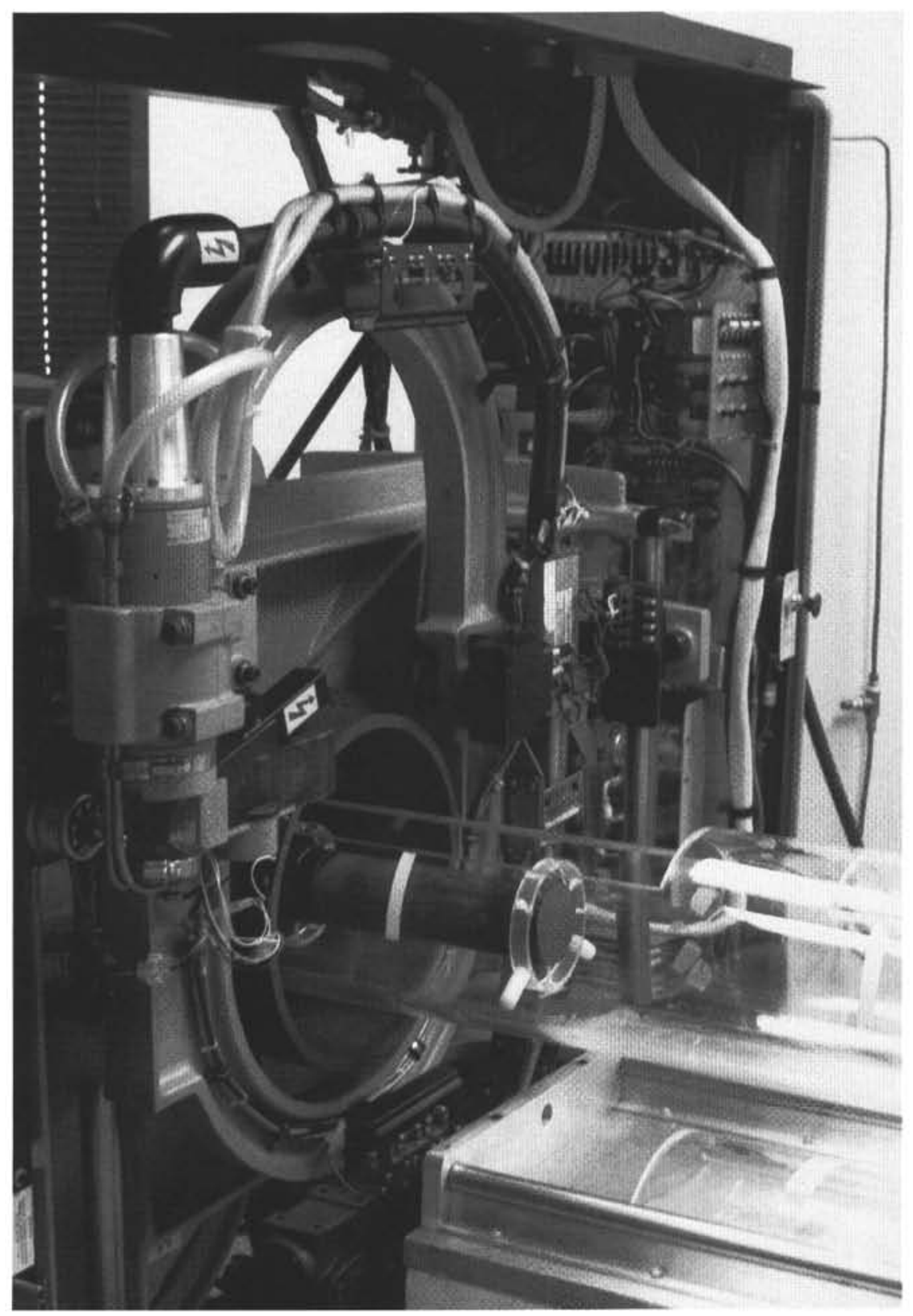

Plate 1. Side view (along scan plane) of the Technicare $\Delta-100$ CT scanner. The basic components of a CT scanner are the $\mathrm{X}$-ray source, detector array, automatic micropositioning table, and central control computer (not shown). 

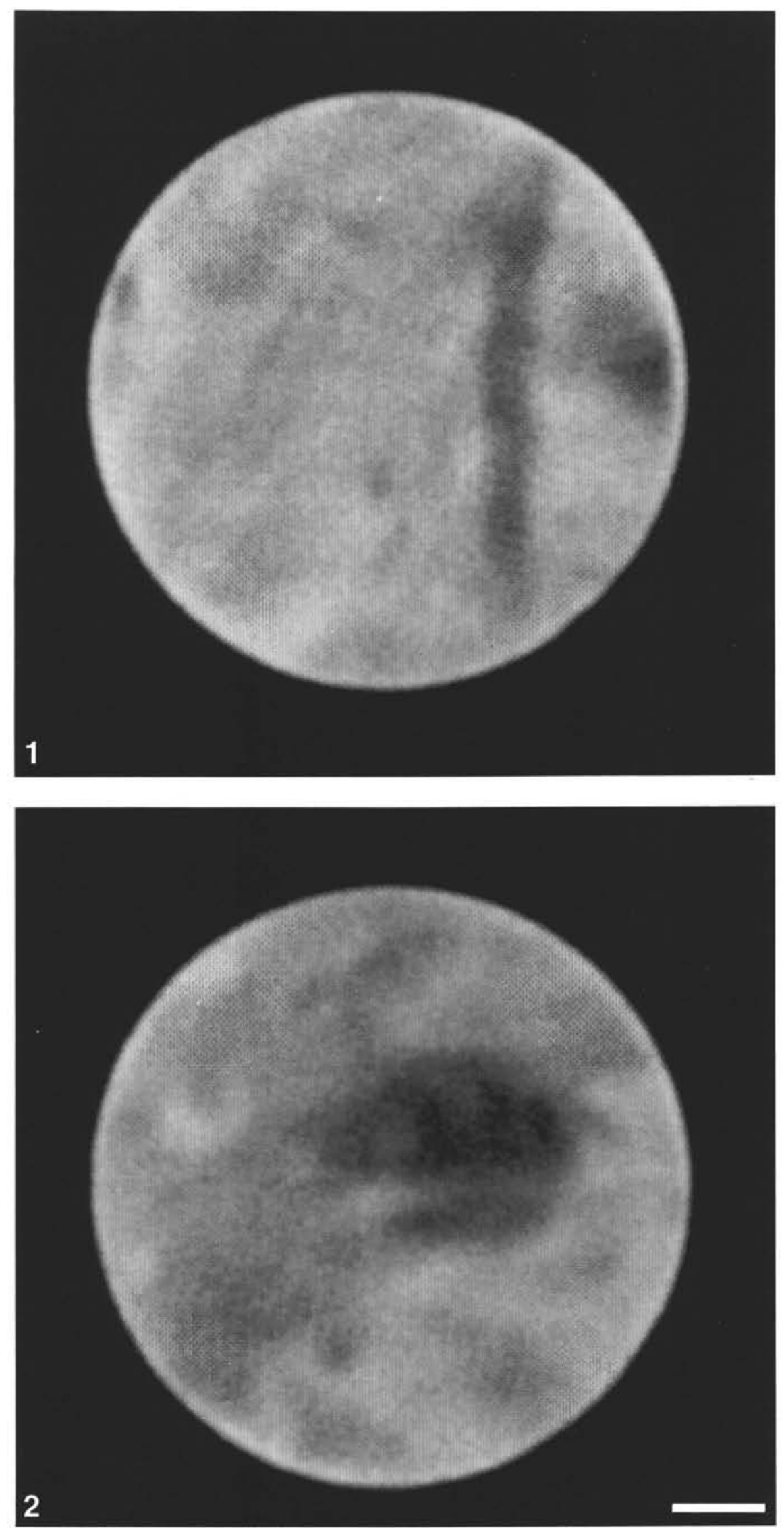

Plate 2. Selected CT images from Sample $145-886 \mathrm{C}-2 \mathrm{H}-4,138-150 \mathrm{~cm}$. 1. Low-density burrow (Planolites) and beginning of the large feeding structure imaged in (2). 2. Large low-density structure and two high-density halo burrows. Scale bar $=1 \mathrm{~cm}$. 

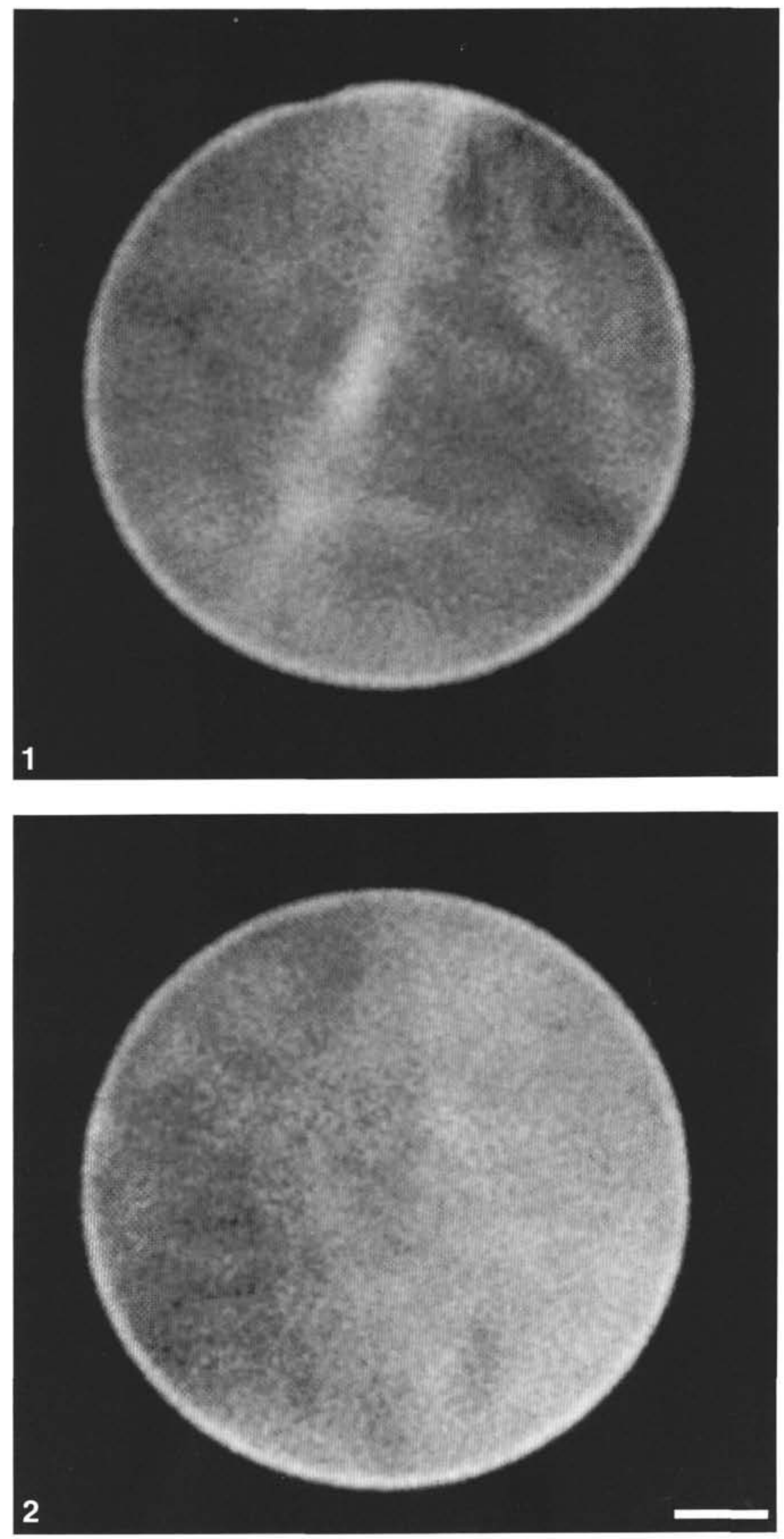

Plate 3. Selected CT images from Sample $145-886 \mathrm{C}-3 \mathrm{H}-5,140-150 \mathrm{~cm}$. 1. High-density burrow. 2. Homogeneous fabric. Scale bar $=1 \mathrm{~cm}$. 

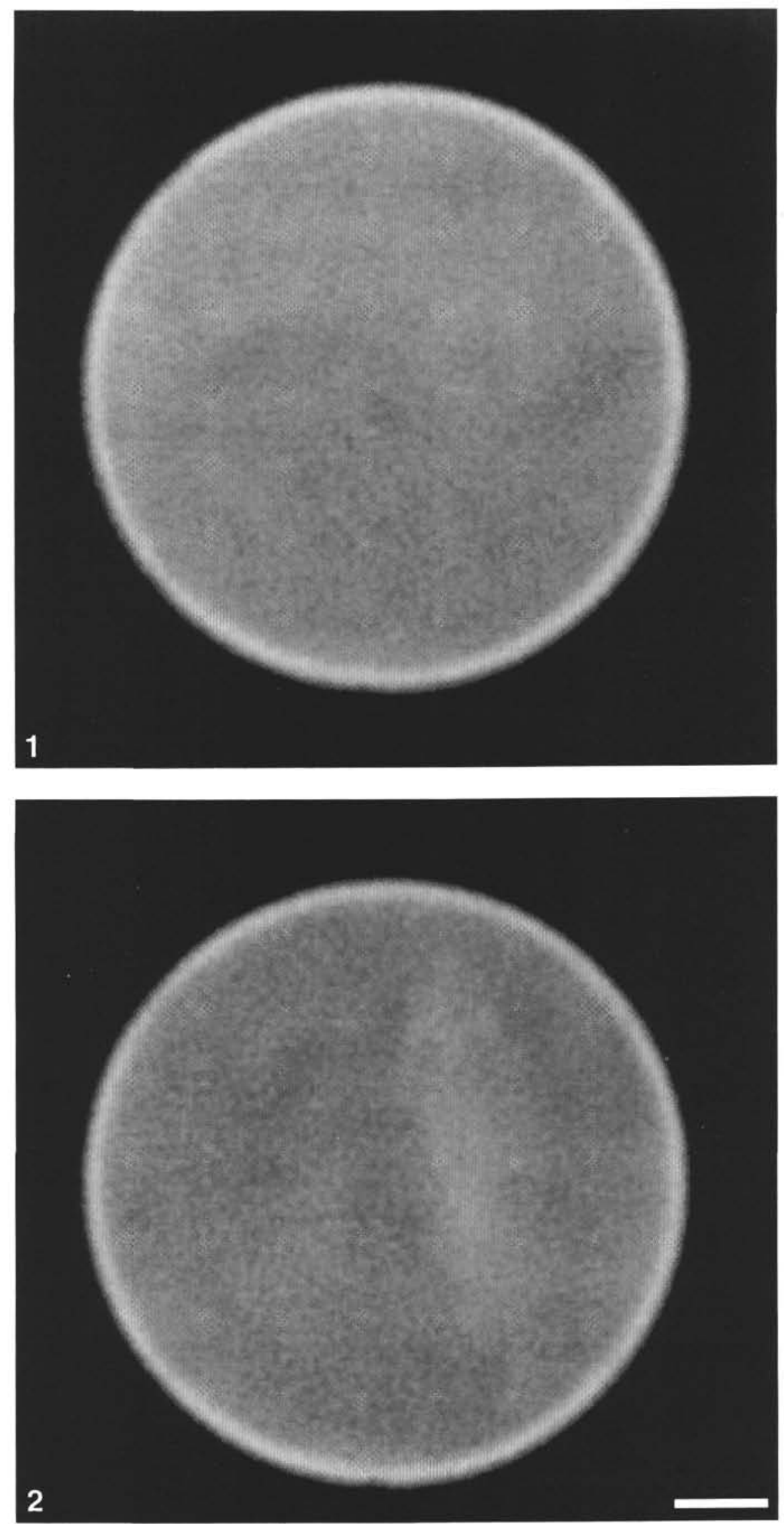

Plate 4. Selected CT images from Sample 145-886C-4H-4, 138-150 cm. 1. Homogeneous fabric. 2. Remnant of high-density burrow (?). Scale bar $=1 \mathrm{~cm}$. 

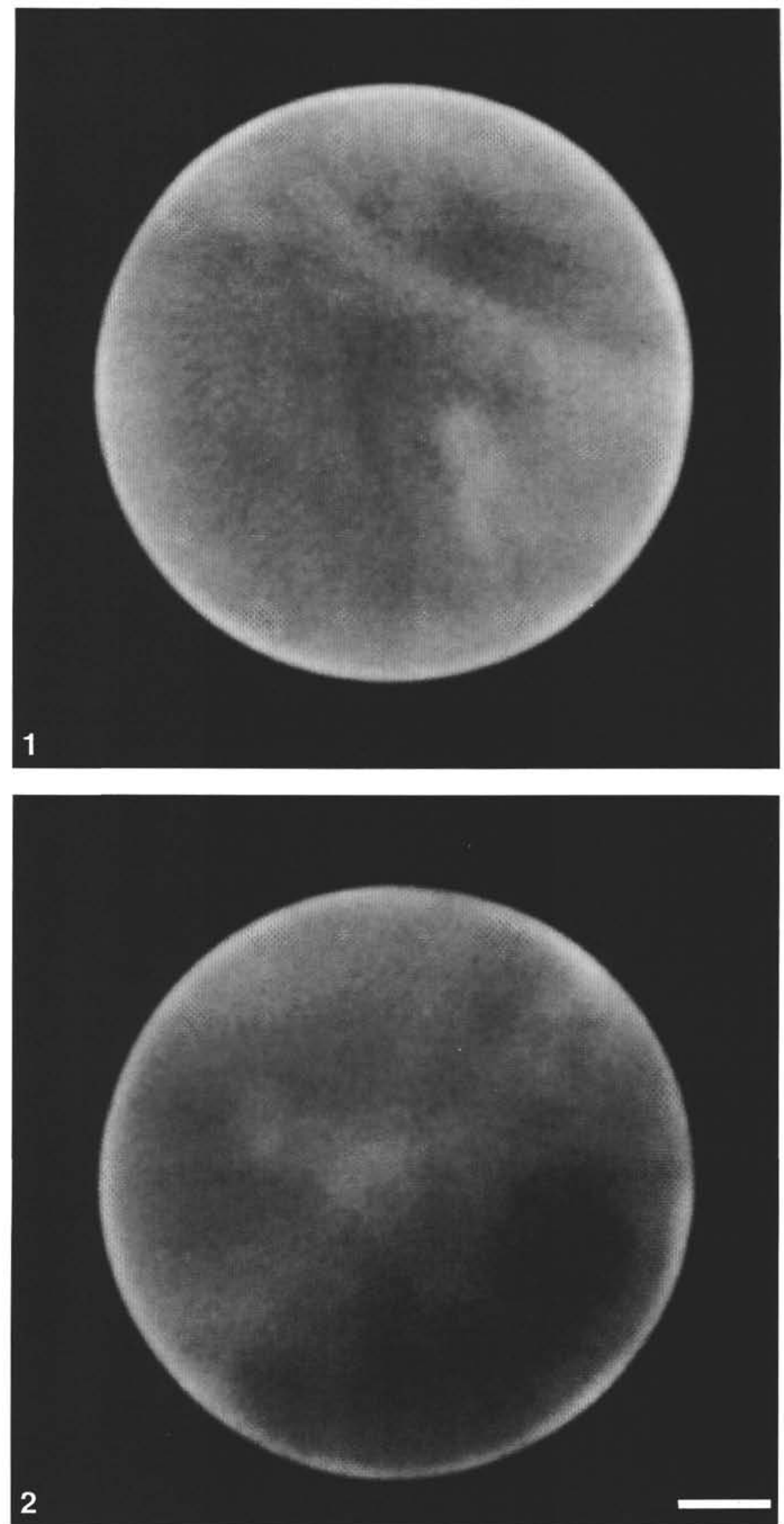

Plate 5. Selected CT images from Sample $145-886 \mathrm{C}-8 \mathrm{H}-5,138-150 \mathrm{~cm} . \quad$ 1, 2. Traces of high-density burrows (?). Scale bar $=1 \mathrm{~cm}$. 